\title{
Sobre o diferencial estrutural e desafios das instituições financeiras cooperativas no ambiente regulatório brasileiro
}

\author{
(On the estrutural difference and challenges \\ of cooperative financial institutions in the structural \\ Brazilian regulatory environment) \\ Ênio Meinen ${ }^{1}$ \\ Diretor de operações do Banco Cooperativo do Brasil (Bancoob) \\ Ronaldo Gaudio 2 \\ Presidente do Instituto Brasileiro de Estudos em Cooperativismo
}

Sumário: Introdução. I. Situação do Sistema Financeiro Cooperativo e Vinculação do Estado. II. Elementos Justificadores da Defesa do Cooperativismo Financeiro. 2.1. Desenvolvimento Socioeconômico Sustentável: Objetivos do Estado Materializados no Modelo Econômico Cooperativista. 2.2. Vantagens da Vocação Estrutural das Cooperativas. 2.3. Diferencial das Instituições Financeiras Cooperativas. III. Práticas de Gestão Virtuosas: Oportunidades e Desafios para um Novo Ciclo de Crescimento. IV. À Guisa de Conclusão. V. Bibliografia.

Resumo: O papel do Estado em relação às cooperativas deve ser congruente com as vantagens potenciais do cooperativismo, com as diretrizes constitucionais para esse sistema e não sujeito a simples oscilação de percepções político-partidárias. O momento regulatório favorável deve ser aproveitado para expansão, consolidação e distinção exemplar do sistema de crédito cooperativo (ou, mais adequadamente, sistema financeiro cooperativo) através de superação de desafios, com práticas de gestão compatíveis, eficientes, mas que previnam a desnaturação da espécie cooperativa.

Palavras-chave: cooperativismo, direito, mercado financeiro, gestão.

1 Master of Business Law (FGV) e MBA in Strategic Management of Human Resources (UFRGS).

2 Presidente da Comissão Especial de Direito Cooperativo da Ordem dos Advogados do Brasil - Seção Rio de Janeiro. MBA em Direito dos Negócios (FGV). Correo electrónico: gaudio@gn.adv.br. 
Abstract: The role of the State in relation to cooperatives should be congruent with the potential benefits of the cooperative, with the constitutional guidelines for the system and not subject to simple oscillation of political perceptions. The favorable regulatory time must be used for expansion, consolidation and exemplary distinction of the cooperative credit system (or, more properly, cooperative financial system) through overcoming challenges with consistent management practices, efficient, but avoiding denaturation of cooperative as a society specie.

Key words: cooperatives, law, financial market, management. 
«Hoy la principal tarea del pensamiento cooperativo ya no consiste en demostrar la superioridad del cooperativismo en tanto que solución o sistema, sino en escrutar los problemas que debe resolver para proseguir su crecimiento»

Georges Lasserre 3

\section{Introdução}

O «cooperativismo de crédito», melhor designado, contemporaneamente, em razão da abrangência das atividades econômicas desenvolvidas e do mercado em que se inserem as cooperativas, como cooperativismo financeiro ${ }^{4}$, atravessou um longo período de retração, mercê da adversa intervenção regulatória do Estado.

Ao lado dos motivadores governamentais que porventura conduziram ao corrente reposicionamento do Banco Central do Brasil (BACEN) —órgão de supervisão do mercado financeiro brasileiro-, militam, entretanto, todos os elementos jurídico-socioeconômicos do Cooperativismo no sentido da imposição ao Estado do dever negativo de opor barreiras à plena participação e expansão das atividades das instituições financeiras cooperativas (IFs cooperativas); além de condutas gerais positivas, ancorados em normas programáticas, relacionadas com a indução estatal na Ordem Econômica e a propiciação de ambiente jurídico adequado para o seu funcionamento regular e seguro.

Tratam-se de imposições em defesa dessas cooperativas, que se justificam pelos superiores efeitos decorrentes de sua natural vocação, a

3 LASSERRE, Georges. El Cooperativismo. Barcelona: Oikos-tau, 1972, p. 115/116.

4 Propõe-se uma relevante evolução terminológica a bem do empreendimento cooperativo, de forma a dar maior visibilidade à condição de instituição financeira completa dos sócios, exaltando a sua verdadeira vocação mercadológico-operacional. Com efeito, o setor —até por necessidade - migrou de uma monoplataforma, baseada na intermediação financeira (captação e empréstimos), para um multiportfólio de soluções negociais (captação, crédito e serviços financeiros). Assim é que "cooperativa de crédito» passa a assumir a identidade de "instituição financeira cooperativa»; "cooperativismo de crédito» é sucedido por "cooperativismo financeiro» e "sistema de crédito cooperativo» ascende para "sistema financeiro cooperativo». Essas (re)definições não representam meros modismos, e nem conflitam com o marco regulatório vigente, haja vista o disposto no art. $2^{\circ}$ da Lei Complementar 130, de 2009. Ademais, «financeiro» é gênero que incorpora a espécie «crédito». 
serem produzidos se respeitadas as características essenciais da espécie societária e do modelo econômico.-

De toda sorte, cambiado de forma muito positiva o ambiente regulatório, os grandes desafios que se apresentam às cooperativas são aqueles concernentes a um crescimento sólido, mas compatível com as peculiaridades dessas sociedades e que conformam a sua identidade a ser preservada.

O novo cenário, mais estável e mais aberto, permite estratégias mais arrojadas de expansão e fortalecimento, que neste trabalho são propostas em defesa de um desenvolvimento seguro e eficiente do sistema financeiro cooperativo.

\section{Situação do Sistema Financeiro Cooperativo e Vinculação do Estado}

Tratando-se o Cooperativismo ${ }^{5}$ de um modelo ou sistema econômico que convive com sistemas econômicos oficiais ${ }^{6}$, preponderantes, vários são os desafios daí decorrentes.

Waldírio Bulgareilli, ao abordar o fato, menciona como desafio a concentração de empresas estatais e empresas capitalistas a impedir o ingresso de cooperativas no mercado, parecendo que a estas somente se poderia reservar os setores e localidades em que o capital especulativo não tivesse interesse, subestimando-se o "papel extraordinário» por elas representado para a humanização da economia e no aperfeiçoamento moral do homem?7.

A ideia de Constituição formal progressista e a forma de atuação do Estado institucionalizam e legitimam o Capitalismo, assim como re-

5 Sem olvidar que o Cooperativismo representa um movimento internacional, uma ideologia, uma filosofia e possa ser o fato que será o suporte inicial de um ramo autônomo do Direito, não poderemos para o presente propósito arraigar a utilidade de demonstrá-lo como sistema econômico. Entretanto, recomenda-se PINHO Carlos Marques e PINHO, Diva Benevides. Sistema Econômicos Comparados. São Paulo: Saraiva: Editora da Universidade de São Paulo, 1984, p. 96/104.

6 Obras interessantes demonstram o funcionamento e desafios do Cooperativismo dentro do Sistema Socialista cubano: MUSA, Orestes Rodríguez. Socialismo, Cooperativismo y Derecho. Dialética necessária para la actualización del modelo económico cubano, artigo em Boletín de la Asociación Internacional de Derecho Cooperativo, n. ${ }^{\circ}$ 46. Bilbao/ES: Publicaciones de la Universidad de Deusto, p. 79/105. E HARNECKER, Camila Piñedo (coord). Cooperativas e socialismo: uma mirada desde Cuba. La Habana: Editorial Caminos, 2012.

7 BULGARELLI, Waldirio. As sociedades cooperativas e sua disciplina jurídica. 2. ${ }^{\text {a ed., }}$ Rio de Janeiro: Renovar, 2000, p. 15. 
primem as manifestações econômicas não alinhadas ao modelo hegemônico. Quanto mais programática — «na medida em que define direitos que não garante, na medida em que esses direitos só assumem eficácia plena quanto implementados pelo legislador ordinário ou por ato do Executivo» ${ }^{8}$ - a Constituição formal mais evidenciará ser um instrumento retórico de dominação da ostensiva maior parte dos cidadãos ao sistema dominante.

Esse fenômeno pôde ser observado claramente no que diz respeito às "cooperativas de crédito», por longo período relegadas injustificavelmente a intensas restrições quanto ao espectro de operações e de adesão do quadro social ${ }^{9}$.

Atualmente, outros segmentos de cooperativas estão sendo duramente ameaçadas por iniciativas baseadas na concentração do capital especulativo, sob o endosso estatal, uma vez que os mercados e localidades anteriormente desinteressantes para a especulação ganharam relevância, tal como ocorre com as cooperativas de taxistas. Alguns desses mercados, ademais, tornaram-se atrativos justamente porque foram erigidos por cooperativas -o que ocorre com as cooperativas de infraestrutura (denominadas tradicionalmente como de eletrificação rural) ${ }^{10}$.

Enquanto os desvios e abusos perpetrados pelas estruturas societárias de propósito puramente lucrativo induzem iniciativas para aperfeiçoar os «templates» normativos, as reações ao desvio das cooperativas seguem a linha da não credibilidade e até da criminalização do modelo econômico ${ }^{11}$.

8 Acerca do indispensável aprofundamento desse argumento, é fundamental a obra clássica de GRAU, Eros Roberto. A ordem econômica na constituição de 1988. 17. ${ }^{a}$ ed., São Paulo: Malheiros, 2015, p. 38/46.

9 PINHO, Diva Benevides. Brasil: crédito cooperativo e sistema financeiro. São Paulo: Esetec, 2006, p. 51/68.

10 «(...) o Estado brasileiro tem sido de uma falsidade inacreditável em relação ao sistema cooperativo nacional, tanto que embora tenha apoiado todas as resoluções internacionais, visando à proteção do movimento cooperativo (...) e finalmente a Resolução n. ${ }^{\circ} 1.413$, de 1969, do Conselho Econômico e Social da ONU, em que se formulava a atuação das cooperativas às metas visadas na chamada Década do Desenvolvimento (...) jamais, as cumpriu, pelo contrário, ainda hoje, as persegue, sobretudo pela imposição de óbices burocráticos e fiscais.» In: BULGARELLI, Waldirio. Op. Cit., p. 8.

11 Já mencionado, nesse contexto, é singular a percepção dos mecanismos constitucionais que permitem ao Estado cumprir justamente burilar o sistema capitalista para preservá-lo, sendo para tanto a Constituição formal, progressista e programática um profícuo e histórico instrumento para a manutenção das classes dominantes. O Estado atua sobre o domínio econômico justamente para evitar a superação do sistema capitalista, preservando-o, renovado, sob diverso regime: GRAU, Eros Roberto. A ordem econômica na constituição de 1988. 17. ${ }^{a}$ ed., São Paulo: Malheiros, 2015, p. 43/44. 
Sobre o cenário do cooperativismo financeiro atual, no contexto da intervenção estatal sobre a Ordem Econômica, não são ocultas as razões para a atual política governamental convergir para a opção cooperativista em um mercado financeiro cada vez mais concentrado e menos concorrente.

«Uma das principais preocupações do Governo é facilitar o acesso a serviços financeiros para todos os brasileiros e, assim, promover sensível redução nos spreads das atividades de intermediação financeira, a partir de maior concorrência. Nesse contexto, o Conselho Monetário Nacional e o Banco Central do Brasil regulamentaram diversas ações e instrumentos com vistas à ampliação dos mecanismos facilitadores de acesso da população ao Sistema Financeiro» ${ }^{12}$.

A declaração do Ministro Alexandre Tombini, presidente do Bacen, evidencia a utilização das cooperativas com o seu potencial de correção dos desvios e desequilíbrios do modelo econômico hegemônico. A oportunidade das cooperativas merece ser percebida para tanto mais que uma forma pontual de intervenção na ordem econômica (in casu, no mercado financeiro), mas de cumprimento de diretivas constitucionais que vinculam o legislador.

Iniciando a superação da perspectiva de iniciativas governamentais meramente circunstanciais, as sucessivas inovações neste setor econômico para as cooperativas foram positivamente alicerçadas, em 2009, sobre um marco regulatório novo, mitigando os riscos de oscilação do alvedrio político-partidário.

Conquanto o atual ambiente jurídico-regulatório seja favorável, a Constituição da República Federativa do Brasil (CFRB), programática, dirigente, impõe ao Estado vinculações («normas-tarefa» e «normasfim») dirigidas tanto à preservação, renovação e fortalecimento do modelo econômico hegemônico, quanto comandos dirigidos à ampla inserção e ampliação do cooperativismo ${ }^{13}$ no mercado.

12 TOMBINI, Alexandre. Desafios para o crescimento do cooperativismo de crédito na visão do Banco Central. Artigo em Conjuntura e Perspectivas do Cooperativismo de Crédito. Publicação coordenada pela Gerência de Apoio ao Desenvolvimento em Mercados (Gemerc). Brasilia: SESCOOP, 2008, p. 23.

13 A ideia vinculação do Estado-legislador está ligada ao conceito de constituição programática ou dirigente, que merece atenção especial para o estudo da Intervenção Estatal sobre a Ordem Econômica. Pelo que recomendamos CANOTILHO, J.J. Gomes. Direito constitucional e teoria da constituição. 7. ${ }^{a}$ ed. Coimbra: Almedina, 2003, p. $217 / 218$. 
A Constituição brasileira, promulgada em 1988 após longo regime de autoritarismo institucionalizado, albergou diretrizes de histórica discussão no Movimento Cooperativista ${ }^{14}$, vinculando o Estado Brasileiro e o Cooperativismo a 3 (três) grandes diretrizes direta e indiretamente relacionadas à intervenção na ordem econômica: são as ordens gerais de Liberdade, Fomento e Adequação, traduzidas essencialmente dos artigos $5 .^{\circ}$, inc. XVII; 146, inc. III, «C» e 174, §2. .

\section{LIBERDADE}

A liberdade de constituição de cooperativas não dissocia a Liberdade de Associação e Livre Iniciativa, dado o propósito econômico desta associação' ${ }^{15}$ de pessoas. De tal maneira, vedar certas atividades econômicas às cooperativas, desobedecida a isonomia que deve existir com outras espécies societárias, implicará indireta, mas indissociavelmente, restrição à liberdade de associação e constituição de cooperativas.

Embora a questão guarde dimensões que não podem ser apreciadas nesta oportunidade, é minimamente necessário registrar o argumento de que o cerceamento à constituição de cooperativas, mercê da expressão «na forma da lei», prevista no inciso XVII do art. $5 .^{\circ}$ da CFRB, não deve estar sujeito meramente a liberalidades de políticas de governo. Em última e sumária análise, a citada norma constitucional, cláusula pétrea (art. $60, \S 4 .^{\circ}$, inc. IV, CF/88), assegura o direito fundamental de associação de indivíduos de constituírem empreendimento próprio que Ihes propiciará, sem o capital especulativo como intermediário, exercerem suas atividades laborais ou realizarem suas aspirações ou necessidades de consumo.

\section{FOMENTO}

O fomento ao Cooperativismo, conforme leciona Waldiki Moura ${ }^{16}$, é diretriz que deve pautar a intervenção do Estado sobretudo nos países em desenvolvimento, uma vez que neles inexistem condições pró-

14 Diferentes matizes das questões cooperativsitas constitucionalizadas podem ser analisadas na obra de DE ROSE, Marco Túlio. A Interferência Estatal nas Cooperativas (Aspectos Constitucionais, Tributários, Administrativos e Societários). Porto Alegre: Sergio Antonio Fabris Editor, 1988.

15 Não os referimos aqui, a espécie de pessoa jurídica denominada associação.

16 MOURA, Waldiki. Curso Médio de Cooperativismo. Rio de Janeiro: Ministério da Agricultura, 1968, p. 182. 
prias para a sobrevivência de um modelo socioeconômico socializante em ambiente competitivo com as espécies societárias mais capitalizadas, baseadas na produção de lucro subjetivo. Mas não é só. O exercício das características essenciais das cooperativas em geral ${ }^{17}$ e dos melhores padrões de operação das «cooperativas de crédito» em específico, gera o círculo virtuoso que plasmará efeitos altamente motivadores do apoio estatal, conforme se analisará.

Apesar do comando constitucional de que as cooperativas devem receber da lei apoio e estímulo, elas, exceto hodiernamente as de crédito, não recebem muita atenção quanto à sua compreensão e ao aperfeiçoamento de seu regime jurídico; muito menos lei que as fomente. ${ }^{18}$

\section{AdequaÇão do ReGIME}

O comando de adequação é explicitado na carta constitucional para assegurar o atendimento da necessidade de conformação da tributação das cooperativas em razão das particularidades e diferenciais que imporiam regras conformes.

Trata-se de uma exigência, a rigor, natural e decorrente do diferencial do fato econômico-jurídico próprio das cooperativas, especialmente em razão da finalidade das cooperativas e da característica da Dupla Qualidade - que, a rigor, se materializa não somente para o campo das relações jurídicas tributárias, mas quaisquer outras, na exata medida do diferencial, através de normas mais refinadas possíveis $^{19}$.

17 GAUDIO, Ronaldo Chaves e FARIAS, Eduardo Helfer de. Barreiras da razão indolente ao Cooperativismo: violação e incompreensão das características essenciais das sociedades cooperativas como fatores de prejuízo socioeconômico. Artigo in Anais do $4^{\circ}$ Seminário Interdisciplinar em Sociologia e Direito. Niterói: Ed. PPGSD-UFF, 2014, p. 49/51, acesso em http://sociologiaedireito.com/wp-content/uploads/2015/01/GT7. pdf, $11 / 04 / 2015$.

18 «(...) o Estado brasileiro tem sido de uma falsidade inacreditável em relação ao sistema cooperativo nacional, tanto que embora tenha apoiado todas as resoluções internacionais, visando à proteção do movimento cooperativo (...) e finalmente a Resolução n. ${ }^{\circ} 1.413$, de 1969, do Conselho Econômico e Social da ONU, em que se formulava a atuação das cooperativas às metas visadas na chamada Década do Desenvolvimento (...) jamais, as cumpriu, pelo contrário, ainda hoje, as persegue, sobretudo pela imposição de óbices burocráticos e fiscais.» In: BULGARELLI, Waldirio. Op. Cit., p. 8.

19 «Essa nova e diferente realidade — a cooperação- carece da condigna consideração jurídica que se lhe reconheça apropriadamente as suas características e sua natureza, sem a forçar a encaixar-se em categorias previstas para fenómenos sociais diferen- 
No contexto do refinamento das normas, Rui Namorado salienta a necessidade das particularidades da operação das cooperativas em cada mercado induzam a elaboração de feixes normativos próprios ${ }^{20}$, metodologia que inspirou, além do Código Cooperativo português, as leis especiais setoriais das cooperativas.

Para as IFs cooperativas, é possível acreditar que, após a CFRB/88, tenha o Estado dedicado a primeira iniciativa de estruturar um regime jurídico conforme (adequado), que identifique e regulamente na medida da justa peculiaridade tanto aspectos do modelo econômico quanto da espécie societária. É o que ocorre especialmente a partir de 2009.

A tentativa de conformar um regime apropriado para as cooperativas cuja operação econômica com seus sócios envolve trabalho foi parcialmente, e com maior ou menor acerto, estabelecida em 2012, com a Lei Ordinária n. ${ }^{\circ}$ 12.690. Entretanto, subsistem reacionárias manifestações sociais fechadas em axiomas que impedem a compreensão da efetiva natureza das relações de trabalho estabelecidas entre cooperativa e sócios, a partir do contrato plurilateral de sociedade, culminando, inclusive, em frágeis e pragmáticas construções jurídicas que vedam o acesso dessas pessoas jurídicas ao mercado dos contratos públicos. ${ }^{21}$

Importa o reconhecimento de que, de toda sorte, o tratamento adequado a um fato ou modelo econômico, assim como às espécies societárias e tipos contratuais é tarefa permanente, que se burila conforme as experiências que se sucederão, tal como, com mais evidência e recorrência, se manifesta em relação às espécies mais alinhadas às operações e estruturas societárias hegemônicas. Historicamente, o constante aperfeiçoamento ocorre, também e por exemplo, com as mais mundanas espécies contratuais como a compra e venda, o con-

tes. Suge assim no campo jurídico a noção de acto cooperativo, não como uma criação caprichosa e arbitrária da teoria jurídica, mas imposta pela necessidade de reconhecimento de uma realidade nova e distinta». Em: CRACOGNA, Dante. O Acto Cooperativo. Artigo em NAMORADO, Rui e OLIVEIRA, Celso Claro de (coord). Pensamento Cooperativo - As Relações entre Cooperativas e Cooperadores, n. ${ }^{\circ} 3$ - ano 3. Lisboa: Tipografia Peres, 2002, p.177.

20 NAMORADO, Rui. Introdução ao Direito Cooperativo - para uma expressão jurídica da cooperatividade. Coimbra: Almedina, 2000, p. 171.

21 GARCIA, Flavio Amaral e GAUDIO, Ronaldo. Artigo publicado no Capítulo 5 Administração Pública e Cooperativismo, em MENDES, Gilmar Ferreira e BRANCO, Paulo Gustavo Gonet (org). III Seminário Internacional de Direito Administrativo e Administração Pública: gestão pública - inovações, eficiência e cooperação no âmbito da administração pública. Brasília: IDP, 2014, p. 105/110. 
trato de emprego, mas que não se confundem com o negócio cooperativo ${ }^{22}$. No Brasil, a exemplo de alguns outros países, a previsão legal desta espécie obrigacional evidencia a necessidade de conformação própria do regime dos negócios praticados pelas cooperativas: o art. 79, da Lei Federal n. ${ }^{\circ}$ 5.764/71, que aqui institui e consagra o ATO COOPERATIVO.

\section{Elementos Justificadores da Defesa do Cooperativismo Financeiro}

Elementos gerais do Cooperativismo e específicos da IFs cooperativas explicitam a necessidade de defesa do sistema financeiros cooperativo.

\subsection{Desenvolvimento Socioeconômico Sustentável: Objetivos do Estado Materializados no Modelo Econômico Cooperativista}

Em uma ordem econômica que privilegia a livre iniciativa, é o fomento uma ferramenta do planejamento estatal23 e o fomento às cooperativas, norma constitucional programática constante do art. 174, vincula-se ao planejamento econômico pelo Estado por inúmeras possibilidades de intervenção por indução ${ }^{24}$-o que se justificaria pelo fato das cooperativas ostentam em sua matriz objetivos, princípios e valores que se alinham ao conceito adequado de Desenvolvimento Econômico.

22 Nos reportamos a formulação doutrinária de Antônio Salinas Puente. Tais relações jurídicas estruturaram a ideia e os primeiros conceitos de Ato Cooperativo (ou, atualmente, negócio cooperativo, a partir da Teoria dos Fatos Jurídicos encampada pelo Código Civil de 2002, art. 104 e seguintes). Vide: PUENTE, Antônio Salinas. Derecho Cooperativo. México: Editorial Cooperativo, 1954, p. 128/158. O conceito se assenta sobre as caraterísticas essenciais das cooperativas, notadamente sobre a Dupla Qualidade dos sócios. Como não é utilizado em todos os países, ao contrário do que ocorre quanto à constatação da citada característica que efetivamente marca o paradigma negocial (operacional) dessas sociedades, é possível prescindir da análise do conceito para o propósito do artigo, mormente porque ainda tem comportado infindáveis discussões,

23 SOUTO, Marcos Juruena Villela. Direito Administrativo da Economia. 3. ${ }^{\circ}$ Ed, Rio de Janeiro: Lumen Juris, 2003, p. 39.

24 GRAU, Eros Roberto. A Ordem econômica na Constituição de 1988 (Interpretação e crítica). 12. ${ }^{a}$ Ed. São Paulo: Malheiros, 2007, p. 148/151. 
Considerando todos os objetivos do Estado, há muito se superou a ideia temerária que limita o conceito de desenvolvimento econômico a crescimento econômico ${ }^{25}$. A Economia também há muito prescreve que o desenvolvimento se caracteriza quando há:

«1) crescimento do bem-estar econômico, medido por indicadores de natureza econômica, por exemplo: produto nacional total, produto nacional per capita;

2) diminuição dos níveis de pobreza, desemprego e desigualdade; e

3) melhoria das condições de saúde, nutrição, educação, moradia e transporte. ${ }^{26}$

Sendo pródiga também a doutrina jurídica a esse respeito ${ }^{27}$, é válido minimamente registar que o Direito Constitucional Econômico Brasileiro somente reconhece como desenvolvimento efetivo aquele que observe harmoniosamente os princípios da art. 170, CR/88: soberania nacional, propriedade privada, função social da propriedade, livre concorrência, defesa do consumidor, defesa do meio ambiente, redução das desigualdades regionais e sociais, busca do pleno emprego.

Ao abordar o sentido das normas coercitivas de direito econômico, Modesto Carvalhosa sustenta que a Livre Iniciativa é um direito constitucional relativo justamente em razão do conteúdo efetivo de desenvolvimento:

«Direito oponível erga omnes vê-se reduzido, enquanto instituto, a uma conformação com sua utilidade socioeconômica, com a qual não pode contrastar. Daí as normas imperativas que vedam quaisquer

25 «Dizer que a ordem econômica funda-se na valorização do trabalho do homem e na livre iniciativa significa: $1^{\circ}$ ) o constituinte prestigiou uma economia de mercado, de cunho capitalista; $2^{\circ}{ }^{\circ}$ mesmo capitalista, a ordem econômica deve priorizar o labor humano como valor constitucional supremo em relação aos demais integrantes da economia de mercado; $\left.3 .^{\circ}\right)$ a intervenção do Estado na economia deve atentar para a dignidade da pessoa humana, fundamento não só da ordem econômica, mas da República Federativa do Brasil como um todo (art. 1. ${ }^{\circ}$ III). In: BULOS, Uadi Lammêgo. Constituição

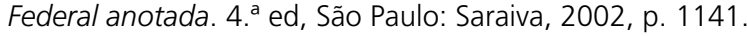

26 PINHO, Diva Benevides e VASCONCELLOS, Marco Antônio S. de. Manual de EConomia. 5. ${ }^{a}$ ed. São Paulo: Saraiva, 2004, p.485.

27 Recomendamos a leitura do capítulo de GRAU, Eros Roberto. Comentário ao art. 170. In. CANOTILHO, J.J. Gomes, MENDES, Gilmar Ferreira, SARLET, Ingo Wolfgang e STRECK (Coords.). Comentários à Constituição Federal do Brasil. São Paulo: Saraiva/Almedina, 2013, p. 1785/1784. 
atos que contrariem o princípio da prevalência do social, no exercício da atividade econômica». ${ }^{28}$

Além, os fundamentos da República, todos de semelhante quilate, orientam o mesmo conteúdo de desenvolvimento: a soberania, a cidadania, a dignidade da pessoa humana, os valores sociais do trabalho e da livre iniciativa (art. $1 .^{\circ}$ e incisos, CF).

Os princípios constitucionais e demais exigências corroboram para a exigência de um desenvolvimento econômico sustentável, que procure diluir as desigualdades regionais ${ }^{29}$. A lógica na organização das cooperativas encontra-se, igualmente, alicerçada no princípio da promoção do desenvolvimento nacional sustentável, cuja dimensão ultrapassa os aspectos ambientais. ${ }^{30}$

Os objetivos da República, consoante art. 3. ${ }^{\circ}$ da Constituição, são construir uma sociedade livre, justa e solidária; garantir o desenvolvimento nacional, erradicar a pobreza e a marginalização e reduzir as desigualdades sociais e regionais; promover o bem de todos, sem preconceitos de origem, raça, sexo, cor, idade e quaisquer outras formas de discriminação. A não discriminação, e.g., é princípio construído vivamente na desde a experiência cooperativista de Rochdale ${ }^{31}$. Mas há muito mais.

Como as cooperativas são sociedades legalmente estruturadas essencialmente para uma distribuição ou aproveitamento mais amplo de riqueza, justificariam, já nessa medida, a norma constitucional de fomento. $^{32}$

28 CARVALHOSA. Modesto. Direito econômico: obras completas. São Paulo: Revista dos Tribunais, 2013.

29 GRAU, Eros Roberto. A ordem econômica na constituição de 1988 (interpretação e crítica). 17. ${ }^{a}$ ed, São Paulo: Malheiros, 2015, p. 212/217.

30 Nesse sentido, cf. completo conceito de desenvolvimento sustentável: «um conceito sistêmico, relacionado com a continuidade dos aspectos econômicos, sociais, culturais e ambientais da sociedade humana. Propõe-se a ser um meio de configurar a civilização e atividade humanas, de tal forma que a sociedade, os seus membros e as suas economias possam preencher as suas necessidades e expressar o seu maior potencial no presente, e ao mesmo tempo preservar a biodiversidade e os ecossistemas naturais, planejando e agindo de forma a atingir pró-eficiência na manutenção indefinida desses ideais». Disponível em: http://www.sustentabilidade.org.br/. Acesso em: 08/09/2011. Para uma profunda abordagem sobre o tema, veja-se FREITAS, Juarez. Sustentabilidade: direito do futuro. Belo Horizonte: Fórum, 2011.

31 Vale conferir o Capítulo Vãos conatos do espírito sectário, em HOLYOAKE, G.J. Os 28 tecelões de Rochdale. (História dos probos pioneiros de Rochdale). Rio de Janeiro: Livraria Francisco Alves, 1933, p. 48/50.

32 A Constituição Italiana segue semelhante linha da Constituição Brasileira em seu artigo 45: "A República reconhece a função social da cooperação com caráter de mutualidade e sem fins de especulação privada.» A rigor, a forma de destinação dos 
Entre as opções de intervenção na ordem econômica para o desenvolvimento econômico e social, o sistema financeiro cooperativo tem sido concretamente utilizado pelo Estado. Especialmente observadas as características essenciais das cooperativas, intrínsecas ao seu modelo econômico e jurídico, pode-se esperar a produção de resultados $^{33}$ que revelam uma profícua aproximação entre os objetivos do Estado e a finalidade dessas sociedades ${ }^{34}$. Estas sociedades representam uma mais eficiente ferramenta de desenvolvimento socioeconômico.

Por possuírem área de admissão de sócios limitada pela capacidade de participação democrática dos membros, pela forma diferenciada de distribuição de excedentes, pela finalidade de atingir melhores patamares econômico-sociais para os sócios enquanto "consumidores» ou trabalhadores. Entre outros fatores intrínsecos, valores e características, é possível constatar que as cooperativas produzem eficiência econômica com maior distribuição de riqueza, com democratização da atividade econômica e desenvolvimento local. ${ }^{35}$

Veja-se como o objetivo das cooperativas (característica essencial), seus princípios e valores; além das outras características que serão tratadas em capítulo próprio, se comunicam com os objetivos do Estado.

O objetivo legal das cooperativas será sempre prestar serviços aos sócios para assegurar-lhes as condições socioeconômicas através do exercício da atividade descrita em seus atos constitutivos.

São os seus valores doutrinários ${ }^{36}$ divididos entre fundamentais (autoajuda, responsabilidade, democracia, igualdade equidade e solida-

resultados da operação econômica das cooperativas liga-se ao que a doutrina tradicional denominou como finalidade dessas sociedades, que consiste na prestação de serviços ao sócio —e não ao capital social—, para incrementar sua condição econômica. Vide FRANK, Walmor. Direito das Sociedades Cooperativas. São Paulo: Saraiva, 1973, pp. 8 e 15.

33 BENECKE. Cooperação e desenvolvimento. O papel das cooperativas no processo de desenvolvimento econômico nos países de Terceiro Mundo. Porto Alegre: Coorjornal, 1980, p. 139/134.

34 MEINEN, Ênio e PORT, Marcio. Cooperativismo financeiro: percurso histórico, perspectivas e desafios. Brasília: Editora Confebrás, 2014, p. 43/44.

35 GAUDIO, Ronaldo Chaves; FARIAS, Eduardo Helfer de. Barreiras da razão indolente ao Cooperativismo: violação e incompreensão das características essenciais das sociedades cooperativas como fatores de prejuízo socioeconômico. Artigo in Anais do $4^{\circ}$ Seminário Interdisciplinar em Sociologia e Direito. Niterói: Ed. PPGSD-UFF, 2014, p. 49/51. Disponível em http://sociologiaedireito.com/wp-content/uploads/2015/01/ GT7.pdf,

36 MIRANDA, José Eduardo de. Op. cit., p. 62/74. 
riedade) e éticos (honestidade, transparência, responsabilidade social e preocupação com os outros indivíduos). ${ }^{37}$

Os princípios cooperativistas, plasmados em diferentes dispositivos da legislação federal brasileira, em especial no art. $4 .^{\circ}$ da Lei 5.764/71, originados nas experiências da cooperativa pioneira de 1844 (princípios rochdalianos) ${ }^{38}$, revisitados pela Aliança Cooperativista Internacional em $1995^{39}$, são adesão livre e voluntária ${ }^{40}$, controle democrático pelos sócios, participação econômica dos sócios, autonomia e independência; educação, treinamento e informação; cooperação entre cooperativas, preocupação com a comunidade ${ }^{41}$.

Tal objetivo, valores e princípios, erigidos muito antes, por exemplo, da Constituição de Weimar ou da Declaração Universal de Direitos Humanos, não-encontram paralelo entre as demais espécies societárias ou modelo privado de exercício da atividade econômica com tamanha afinidade com os objetivos e fundamentos da República ou com o conteúdo de desenvolvimento econômico sustentável.

Esse arcabouço de potencialidades justificaria um cuidado mais depurado com os problemas que impedem o avanço das cooperativas, considerando que claramente se manifestam como uma poderosa ferramenta para o desenvolvimento socioeconômico sustentável, mormente se levado em conta no planejamento estatal ${ }^{42}$, tal como tem empreendido o Bacen, alinhando-se aos preceitos constitucionais para o Cooperativismo para abrir cada vez mais o concentrado mercado financeiro à alternativa das instituições financeiras cooperativas $^{43}$.

37 http://ica.coop/en/whats-co-op/co-operative-identity-values-principles, acessado em 26.11.2014.

38 LUZ FILHO, Fábio. O direito cooperativo. Rio de Janeiro: Irmaõs Pongetti Editora, 1962, p. 31.

39 MIRANDA, Jose Eduardo de. Op. cit., p. 82

$40 \mathrm{http}: / /$ ica.coop/en/whats-co-op/co-operative-identity-values-principles, acessado em 26.11.2014.

41 Sobre o conteúdo axiológico e desenvolvimento histórico do valores e princípios cooperativos, sugerimos a obra: MIRANDA, Jose Eduardo de. Op. cit.

42 Segue-se o conceito de que "planejamento apenas qualifica a intervenção do Estado sobre e no domínio econômico, na medida em que esta, quando consequente ao prévio exercício dele, resulta mais racional.»In: GRAU, Eros Roberto. $A$ ordem econômica na constituição de 1988. 17. ' ed., São Paulo: Malheiros, 2015, p. 146.

43 Sobretudo a partir da Lei Complementar n. ${ }^{\circ}$ 130/2009, conforme é possível constatar em SOUZA, João Batista Loredo de; MEINEN, Ênio. Cooperativas de Crédito: Gestão Eficaz. Brasília: Editora Confebrás, 2010, p. 47/70. 


\subsection{Vantagens da Vocação Estrutural das Cooperativas}

Muito do que recorrentemente se esgrime em nome da Isonomia, mas em desfavor das cooperativas, deságua simplesmente em tratamento não conforme, na medida em que confere às cooperativas tratamento incompatível com a realidade (estrutura) da espécie societária e do modelo de operação econômica. O que muitas vezes é tido como violação de isonomia constitui apenas a tentativa de um regime compatível com a medida das diferenças estruturais dessas sociedades.

De todo modo, é possível arrolar no campo do perfil operacional, com consectários para o regime da espécie societária das cooperativas, aspectos que justificam não só o tratamento conforme, mas favorecido, em razão dos resultados produzidos por esse modelo.

Diga-se, ainda assim, que a atribuição de determinadas prerrogativas 44 às cooperativas não induz uma inconstitucionalidade no campo da Isonomia, sobretudo quando o próprio texto constitucional estatui tal tratamento ${ }^{45}$.

A doutrina identifica a repetição desse padrão nas Cartas Constitucionais de diversos países, dentre eles Bolívia (1967), Coreia do Sul (1948), Costa Rica (1949), Egito (1971), Espanha (1978)46, e.g.

Não existindo inconstitucionalidades entre dispositivos constitucionais (cabendo a harmonização), o modelo estrutural e operacional das cooperativas justifica que sejam credoras de tratamento favorecido. A rigor, o que ocorre com elas é similar às pequenas e micro empresas no art. 170, IX, CF, embora os fundamentos para as cooperativas sejam de maior escol ${ }^{47}$.

44 Com base em fundamentos econômicos, a Constituição reconhece, por exemplo, o tratamento diferenciado e favorecido às microemprersas e empresas de pequeno porte (art. 143, III, «d»; 179), inclusive quanto à tributação (art. 94) e outras relações obrigacionais (art. 46, inc. I).

45 «Art. 174. Como agente normativo e regulador da atividade econômica, o Estado exercerá, na forma da lei, as funções de fiscalização, incentivo e planejamento, sendo este determinante para o setor público e indicativo para o setor privado. (...) § 2. ${ }^{\circ}-$ A lei apoiará e estimulará o cooperativismo e outras formas de associativismo.» (destacou-se)

46 ARAGÃO, Alexandre Santos de. Comentário ao art. 174, §2. ․ In. CANOTILHO, J.J. Gomes, MENDES, Gilmar Ferreira, SARLET, Ingo Wolfgang e STRECK (Coords.). Comentários à Constituição Federal do Brasil. São Paulo: Saraiva/Almedina, 2013, p. 1833.

47 Nesse contexto, cite-se a ilustrativa previsão de favorecimento dirigido às cooperativas no art. 34 da Lei 11.488/2007, materialmente prevendo mesmo favorecimento outorgado às pequenas e micro empresas. O dispositivo que estende as vantagens conferidas às microempresas e empresas de pequeno porte às cooperativas: «Art. 34 . 
Quanto às IFs cooperativas, entretanto, não existe qualquer pleito por tratamento privilegiado nem concessão nesse sentido. Ao contrário, o reclamo diz respeito historicamente a maior adequação regulatória, liberdade e igualdade de inserção no mercado financeiro.

É o diferencial das operações, do compromisso socioeconômico do Cooperativismo e da forma de produção e eventual distribuição de excedentes que justificam a inserção na CFRB/88 do art. 174, § $2^{\circ}$. Convém, portanto, analisar alguns justos motivos para o tratamento diferenciado, favorecido - adiante ensaiado modestamente no plano econômico-social e no plano jurídico.

As microempresas e empresas de pequeno porte também receberam tratamento diferenciado porque, assim como no caso das cooperativas, foi o legislador constituinte originário que pretendeu utilizá-las como instrumentos para concretizar outros valores como a busca pelo desenvolvimento econômico e social e o pleno emprego. ${ }^{48}$ Trata-se de um mecanismo de intervenção estatal por indução, modalidade de atuação estatal que, quando manifestada por lei ou ato normativo, não raro é questionada em sua constitucionalidade ${ }^{49}$.

Concretamente, um primeiro aspecto sobre o diferencial das cooperativas é que as operações realizadas em regime de cooperação geram mais benefícios para o grupo que coopera do que geraria individualmente para cada um se competisse e proporcionam maior eficiência econômica ${ }^{50}$, entendida esta, sumariamente, como a maximização na

Aplica-se às sociedades cooperativas que tenham auferido, no ano-calendário anterior, receita bruta até o limite definido no inciso II do caput do art. 30 da Lei Complementar n. ${ }^{\circ} 123$, de 14 de dezembro de 2006, nela incluídos os atos cooperados e não-cooperados, o disposto nos Capítulos V a X, na Seção IV do Capítulo XI, e no Capítulo XII da referida Lei Complementar.»

48 Veja-se, aliás, que foi inserido, na Lei $n .^{\circ} 11.488 / 2007$, dispositivo que estende as vantagens conferidas às microempresas e empresas de pequeno porte às cooperativas: Art. 34. Aplica-se às sociedades cooperativas que tenham auferido, no ano-calendário anterior, receita bruta até o limite definido no inciso II do caput do art. 30 da Lei Complementar n. ${ }^{\circ} 123$, de 14 de dezembro de 2006, nela incluídos os atos cooperados e não-cooperados, o disposto nos Capítulos V a X, na Seção IV do Capítulo XI, e no Capítulo XII da referida Lei Complementar. Trata-se, em apertada síntese, na possibilidade de participar de licitação mesmo com problemas nos documentos de habilitação (regularidade fiscal) , com prazo de dois dias úteis, prorrogáveis por mais dois, para regularizar o débito, caso seja declarado vencedor do certame; do empate ficto (10\% superior à melhor proposta, sendo este percentual reduzido a $5 \%$ no pregão) e o direito à apresentação de nova proposta pela ME, EPP ou Cooperativa que se enquadre no referido limite de receita bruta.

49 GRAU, Eros Roberto. A ordem econômica na constituição de 1988. 17. a ed., São Paulo: Malheiros, 2015, p. 143/145.

50 Sobre o conceito e ideias em torno de eficiência econômica, recomendamos: PINHEIRO, Armando Castelar; e SADDI, Jairo. Curso de law and economics. Disponí- 
geração e distribuição dos recursos materiais disponíveis em uma dada comunidade.

A Teoria dos Jogos ${ }^{51}$ realiza as demonstrações do fenômeno, comprovando que, em contraposição as operações competitivas, o resultado econômico para o todo é superior, obtendo-se maior eficiência econômica. Quando a postura do "ganhar mais que o outro» consegue ser suplantada pelo "ganhar ainda mais com o outro» - já indiciando, sob essa perspectiva inicial, vantagens do Cooperativismo. A adoção de uma operação em cooperação produz melhores resultados para os jogadores como um todo ${ }^{52}$.

Um segundo ponto diz respeito também ao perfil societário das cooperativas, que, conforme disciplinado pela legislação (art. $4 .^{\circ}$, XII, Lei 5.764/71), envolve, como regra, uma área de admissão de sócios limitada à capacidade de reunião, pretendendo tal contorno ser uma das principais formas de assegurar a existência de um quadro social próximo do centro decisório ou em condições de participarem das deliberações sobre o empreendimento. Essa característica estrutural tem por consequência contribuir para o desenvolvimento local onde se instala ou opera a cooperativa, sendo que o resultado econômico não é distribuído a sócios meramente investidores, sem vinculação com a localidade e tampouco a cooperativa costuma distribuir excedentes ao capital estrangeiro. A riqueza permanece no país e, em especial, nas localidades onde os sócios operam.

Outra caraterística justificadora do fomento é a democratização da iniciativa privada manifestada pela cooperativa ${ }^{53}$. A união de trabalhadores ou consumidores num empreendimento cooperativo permite que assumam o papel de donos. Reúnem-se, na mesma pessoa, dois papéis (dono e cliente/usuário) que no modelo de mercado capitalista estariam em polos de interesses opostos.

Assim sendo, os trabalhadores e os consumidores convertem-se em titulares da empresa que, no modelo hegemônico, estaria simplesmente a buscar remunerar o mínimo possível ou vender ao me-

vel em http://www.iadb.org/res/laresnetwork/files/pr251 finaldraft.pdf., acessado em 03.12.2014.

51 MACKAAY, Ejan; Rosseau, Stéphane. Análise econômica do Direito. 2. ${ }^{a}$ ed., São Paulo: Atlas, 2015, p. 41/86.

52 A guisa de informações básicas, vide: GREMAUD, Amaury Patrick e BRAGA, Mauro Bobik. Teoria dos Jogos: Uma Introdução. In: PINHO, Diva Benevides e VASCONCELLOS, Marco Antônio Sandoval de (org.). Manual de Economia. 3. ${ }^{a}$ ed., São Paulo: Saraiva, 1998, p. 243/257.

53 BECHO, Renato Lopes. Elementos de Direito Cooperativo (de acordo com o Código Civil). São Paulo: Dialética, 2002, p. 132/135. 
Ihor preço possível. Essa dinâmica pretende proporcionar a prática do preço justo ${ }^{4}$ para o cooperador - a melhor remuneração do trabalho extraível do empreendimento ou o melhor produto ou serviço com o menor custo possível.

Nas cooperativas, esses consumidores e trabalhadores, sócios da empresa, participam das deliberações, independente da fração de seu capital na sociedade, exercendo qualquer deles o mesmo peso de voto, o que, também por isso, implica na democratização da iniciativa privada 55

Finalmente, um aspecto diz respeito à forma de distribuição dos excedentes eventualmente produzidos pela operação cooperativa. Sendo superavitário o exercício social, a distribuição do excedente não é feita em remuneração ou na medida do capital social de cada sócio, mas na razão da participação dos cooperados para a formação de tal excedente, devolvendo a cada qual o seu respectivo quinhão. Trata-se da característica do retorno ${ }^{56}$, que consolida nas cooperativas a justiça distributiva. Valoriza-se a atuação do indivíduo e não sua capacidade de investir, proporcionando-se distribuição mais eficiente dos excedentes, ao invés de concentração de riqueza.

Tais fatores são expostos em linhas bastante essenciais e gerais para o presente trabalho, sendo certo que podem ser desdobrados, conforme se poderá encontrar em minuciosos trabalhos doutrinários nesse sentido ${ }^{57}$.

Apesar de tudo isso, grandes desafios ao fomento do Cooperativismo se apresentam pela cristalização do pensar sob a lógica das premissas preponderantes: capitalista, individualista, competitiva. Esses desafios envolvem o conhecimento das caraterísticas essenciais das cooperativas (cooperação, dupla qualidade, finalidade) ${ }^{58}$, pois é justamente a partir dessas características que os diferenciais e as vantagens são produzidos. Negligenciado algum desses elementos, seja pelas próprias cooperativas ou por quem lhes deva regulamentar, fiscalizar ou julgar, não terão essas sociedades condições de cumprir sua elevada vocação.

54 BULGARELLI, Waldirio. Op. cit., p. 21

55 As ideias em obra clássica: WARBASSE, James Peter. Democracia Cooperativa. Buenos Aires: Arengreen, 1975.

56 BULGARELLI, Waldirio. Regime Jurídico das Sociedades Cooperativas. São Paulo: Livraria Pioneira Editora, 1965. 2000), p. 160/162.

57 Vide, por exemplo: BENECKE, Dieter W., Op. cit., p. 109/134.

58 GAUDIO, Ronaldo. Desenvolvimento Econômico e Cooperativismo: fundamentos e desafios à implementação do art. 174, \$2. ${ }^{\circ}$ da Constituição a partir das características essenciais das sociedades cooperativas; (no prelo). 


\subsection{Diferencial das Instituições Financeiras Cooperativas}

Não são poucas as motivações para ser sócio de uma instituição financeira cooperativa ou, simplesmente, apoiador da causa.

Sem desconhecer as vantagens comuns a todos os ramos cooperativos, poder-se-ia iniciar relembrando que nas cooperativas financeiras o destinatário das soluções é o próprio dono do empreendimento, o sócio, ao passo que na atividade bancária clássica o usuário é um terceiro, cliente, estranho à empresa.

Num banco, por mais prestigiado que o usuário possa ser considerado, recebendo atenção diferenciada em razão do volume financeiro que movimenta (tendo à sua disposição até mesmo agências específicas em alguns casos e merecendo nomeação especial), jamais passará de «cliente» de mercado. Na cooperativa, não importando o grau de reciprocidade e o montante de investimentos, todo o usuário é "dono», distinção máxima que faz jus à sua condição societária, sendo que em todas as dependências lhe é conferido o tratamento de proprietário.

É nisso, possivelmente, que reside a essência da distinção. Com efeito, é muito diferente o grau de preocupação e de envolvimento no ambiente cooperativo, onde se lida com o próprio dono do negócio. $\mathrm{Na}$ relação bancária convencional, não há tamanha profundidade de compromisso entre empresa e cliente. Aliás, os interesses são rigorosamente opostos. Enquanto, de um lado, a instituição financeira capitalista pretende prestar serviços financeiros com maior margem de lucro possível e, de outro, o interesse de seus clientes é receber o melhor serviço possível ao menor custo possível; tal assimetria (bilateralidade) de interesses é mitigada nas cooperativas financeiras pela conversão do cliente em dono de uma empresa cujo objetivo e lhe prestar o melhor serviço ao menor custo.

No caso das cooperativas, a desatenção com a expectativa do dono-usuário gera consequências imediatas aos administradores da sociedade, enquanto que nas relações financeiras tradicionais a inconformidade de um cliente não passa de um simples protesto, invariavelmente sem resultado algum, senão quando compensado através de cansativos processos judiciais que o legam a ser apenas uma contingência estatística nos resultados do banco.

Como instrumentos de desenvolvimento local, as cooperativas asseguram a reciclagem dos recursos nas próprias comunidades. Ou seja, o resultado monetário do que se gera é reinvestido ali mesmo, produzindo novas riquezas. Além disso, as entidades têm plena autonomia para ajustar a sua política creditícia e de gestão da poupança 
à realidade do lugar. Essa liberdade permite acompanhar adequadamente o ciclo econômico de cada região e respeitar as suas aptidões e potencialidades sócio-econômico-culturais, com geração e incremento de renda, estimulando, ainda, a fixação dos jovens nas próprias comunidades.

Em síntese, o círculo virtuoso do cooperativismo financeiro vem reproduzido na figura a seguir:

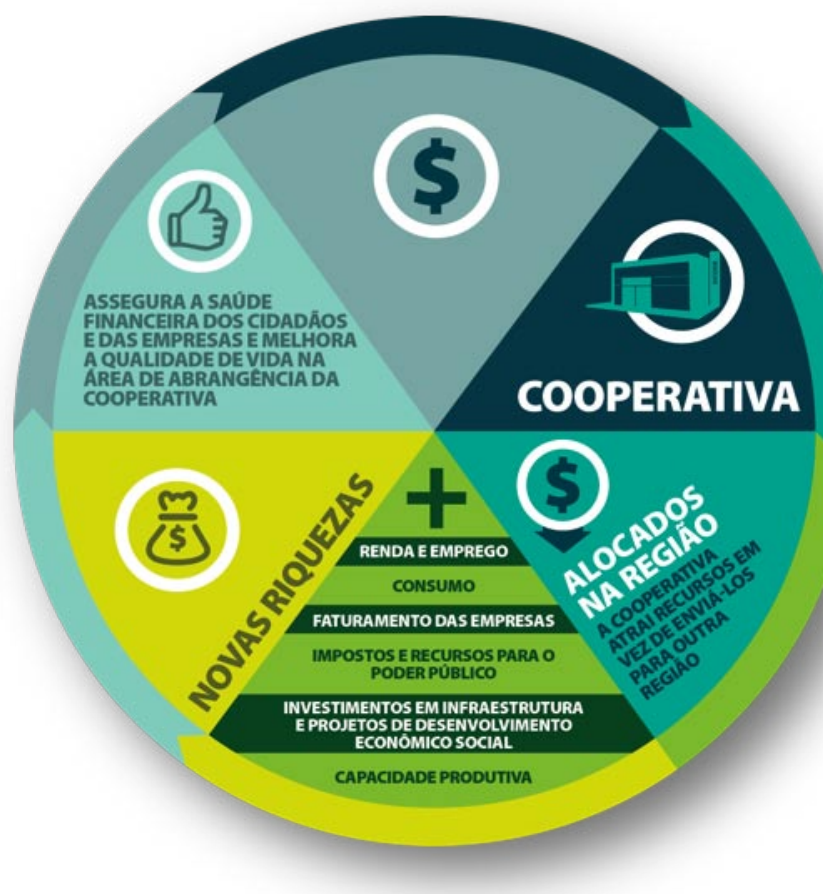

Ou seja, se os investimentos dos cidadãos e das empresas forem destinados às cooperativas, estes, muitas vezes junto com outros recursos captados no mercado financeiro (trazidos de fora), os realocam na mesma região; redistribuídos, geram renda e aumentam o poder aquisitivo da população, que passa a consumir mais; em decorrência, há incremento no faturamento das empresas; vendendo mais, as empresas abrem novas vagas de trabalho, absorvendo especialmente o público jo- 
vem; o aumento nas vendas também repercute na arrecadação de impostos; com mais recursos, o poder público pode investir em infraestrutura e outros projetos de desenvolvimento econômico e social, o que faz ampliar a capacidade produtiva, gerando novas riquezas. O resultado final é a melhora da qualidade de vida na área de abrangência da cooperativa.

Há, também, mais flexibilidade, democracia e justiça no relacionamento negocial entre a cooperativa e seu sócio, na comparação com o relacionamento entre banco e cliente. No meio cooperativo, existe um maior protagonismo por parte de quem é o principal interessado (o usuário-dono). Como corolário, os produtos e serviços vêm ao encontro das expectativas do usuário-dono, alinhando-se à sua vocação e às suas possibilidades econômico-profissionais.

Já o dimensionamento dos excedentes deve ter como referência as necessidades de reinvestimentos (para a solidez e o crescimento) da própria organização cooperativa. O que passar disso deve ser devolvido aos próprios usuários, na proporção de suas operações, medida que, de um lado, faz reduzir a taxa de juros pactuadas nos empréstimos e também as tarifas pagas no exercício, e, de outro, amplia a remuneração dos depósitos. Nesse ponto, aparece com toda a nitidez a singularidade societária representada pelo ato ou negócio cooperativo.

Por isso — pela adequabilidade e suficiência - é que se identifica uma agregação de renda na «contramão». Não há a perspectiva do lucro (que, aliás, é afastado por definição legal). Quem ganha nessa equação não é quem detém o capital (visão da empresa), mas quem se vale das soluções concebidas em formato mutualista, na justa medida das operações econômicas estabelecidas com a cooperativa.

As cooperativas, em razão de seus valores, princípios e das necessidades de seus integrantes —ligados à localidade onde se estabelece a sociedade e onde se concentram suas operações-, não acolhem por critério de inserção de mercado com base nas melhores praças e nos cidadãos e empresas mais afortunados. Dito de outra forma, não deixam as pequenas comunidades e as classes de menor renda ao desamparo. Prova disso é que em $10 \%$ dos municípios brasileiros (em 31/12/13 eram 564 remotas/diminutas comunidades), e para inúmeros grupos de assalariados, as cooperativas são as únicas instituições financeiras a oferecer instalações, estrutura de pessoal e portfólio de operações e serviços decentes. Assim, cumprem um duplo papel nesses locais: promovem o desenvolvimento econômico e asseguram o exercício da cidadania pela inclusão financeira. Nos dizeres de Henrique Meirelles, como ex-presidente do Banco Central do Brasil (BACEN), «a importância do 
cooperativismo de crédito para a economia brasileira baseia-se no binômio concorrência e inclusão financeira» (Revista Sicoob Goiás/Tocantins, edição de outubro/2007).

As cooperativas também se diferenciam no quesito diluição do crédito. Nesse particular, considerando as operações de custeio agrícola ( $R \$ 74,4$ bilhões, base: 2013), o setor é responsável por aproximadamente um quarto de todos os contratos, embora o volume total emprestado seja de apenas 14\%. Enquanto isso, o sistema bancário tradicional privado, detendo $28 \%$ do volume emprestado, responde por apenas $13 \%$ dos contratos. Nessa mesma linha de desconcentração, reforçando a importância socioeconômica das cooperativas, mais um indicador relevante: cerca de $76 \%$ de suas operações de crédito, em todas as modalidades, estão abaixo de $R \$$ $5.000,00$ (cinco mil reais), conforme dados do Banco Central do Brasil (data-base 04/2015):

\begin{tabular}{llllll}
\hline Data-base & Segmento & Faixa Valor & $\begin{array}{c}\text { Qtde } \\
\text { Operações }\end{array}$ & $\begin{array}{c}\text { Percentual } \\
\text { Operações }\end{array}$ & $\begin{array}{c}\text { Valor Carteira Ativa } \\
(\mathrm{R} \$)\end{array}$ \\
\hline 201504 & $\begin{array}{l}\text { Cooperativa } \\
\text { de Crédito }\end{array}$ & $\begin{array}{l}\text { Valor Operação } \\
<5.000\end{array}$ & 9.067 .458 & $76,38 \%$ & $6.800 .054 .823,88$ \\
$\begin{array}{l}\text { Cooperativa } \\
\text { de Crédito }\end{array}$ & $\begin{array}{l}\text { Valor Operação } \\
\geq 5.000\end{array}$ & 2.804 .652 & $23,62 \%$ & $62.802 .151 .021,30$ \\
\hline
\end{tabular}

No que se refere ao público de interesse mais imediato do sistema convencional (de maior renda), tem-se visto movimentos cada vez mais arrojados dos bancos no sentido de recuperar antigos clientes que resolveram migrar para suas próprias instituições financeiras, tornando-se sócios de cooperativas. Para isso, oferecem condições atrativas a esses usuários, notadamente reduzindo spreads, estendendo prazos de suas linhas de crédito, remunerando melhor os investimentos e propondo-se a atendê-los de forma mais personalizada ou atenciosa. Além disso, com o objetivo de reter a clientela e reduzir migrações para as cooperativas, essas instituições têm feito esforços preventivos, tornando mais competitivas as suas soluções, que, a bem da sociedade, acabam beneficiando cidadãos e empresas. Tratam-se de contribuições indiretas geradas pela presença das cooperativas no sistema financeiro.

Nessa linha, o presidente do Banco Central do Brasil, Ministro Alexandre Tombini, como grande conhecedor e incentivador do movimento, proclama que 
«a importância do cooperativismo de crédito para o país concentrase nos objetivos de prover e ampliar a oferta de serviços financeiros, fomentando assim a promoção da inclusão financeira e do desenvolvimento regional. Consequentemente, contribui também para a meIhoria da qualidade e redução dos custos da atividade de intermediação financeira» ${ }^{59}$.

Em outra manifestação, o dirigente máximo do BACEN lembra que «onde há presença forte do cooperativismo, há uma tendência de as tarifas financeiras e as taxas dos empréstimos serem menores do que nos municípios onde o cooperativismo de crédito não está presente». (Depoimento dado por ocasião do lançamento da Agenda Legislativa do Cooperativismo-Brasília/DF, em 28-02-12).

Por fim, Tombini faz ver que

«do ponto de vista dos benefícios esperados para a população, o cooperativismo encaixa-se como luva em um dos pilares do governo para ampliar o acesso aos serviços financeiros para grande parte da população brasileira e estimular a redução no spread da intermediação financeira. (...) A sustentabilidade socioambiental está na gênese do cooperativismo e sua face mais visível é a capacidade de soerguer comunidades, combater desigualdades, inibir usura e levar cidadania às regiões mais carentes. Não sem propósito, ele conta com benefícios da legislação ordinária e complementar, sob percepção de que, ao investir no social, há retorno para todos com geração de cidadania, emprego, renda e preservação do meio ambiente. Por isso, todos devem estar vigilantes quanto a esses objetivos, de forma a não permitir o mau uso dos benefícios e, com ele, o risco de imagem e de retrocesso ${ }^{60}$.

Os benefícios do cooperativismo financeiro, portanto, vão muito além dos cerca de $3 \%$ do Produto Interno Bruto financeiro do País (market share atual). As cooperativas, com efeito, constituem-se em referência no conjunto de fatores que combinam atenção aos propósitos dos usuários, participação destes na gestão (aspecto da maior relevância), envolvimento com as diferentes comunidades e públicos de inte-

59 Entrevista concedida a Revista Sicoob, Ano 2, N. ${ }^{\circ}$ 6, abr/mai/jun 2011, p. 22/26. Disponível em http://www.sicoob.com.br/revistas

60 MELO SOBRINHO, Abelardo Duarte de; TOMBINI, Alexandre. Artigo em PINHO, Diva Benevides e coord.). O Cooperativismo de Crédito no Brasil do século XX ao século XXI. Brasília: Ed. Confebras, 2010. 
resse, precificação e outros aspectos relevantes da atividade de intermediação bancária.

Enfim, sua presença é decisiva no disciplinamento e no maior alcance do mercado financeiro, ainda mais em se tratando de um país com dimensões continentais, cuja estrutura federativa conta com centenas de pequenos e distantes municípios, e cuja estratificação social revela grandes desníveis/distorções, deixando um contingente substancial de cidadãos à margem do progresso e da inclusão social. É dizer que uma é a realidade do sistema financeiro nacional com a presença -em notável progressão- das cooperativas; outra, no entanto, seria na sua ausência. Beneficiam-se, assim, não apenas os sócios, mas também os clientes dos bancos em geral. Ganha, enfim, a sociedade.

No que diz respeito à segurança e solidez do empreendimento, vale frisar que as cooperativas têm de cumprir regras operacionais e diretrizes de governança semelhantes às dos grandes bancos brasileiros, e, para as (pouco prováveis) situações de insucesso, dispõem de fundo intersistêmico nacional (denominado FGCoop) que, em situação extrema, garante o pagamento dos depósitos dos sócios até o limite regulamentarmente definido. Ou seja, têm de reunir capital/ patrimônio suficiente para fazer face aos riscos de suas operações, cumprindo as diretrizes (internacionais) de Basileia; contar com gestores idôneos e qualificados, cujos nomes são submetidos ao BACEN, e acumular reservas, em regime de solidariedade com as coirmãs, para apoiar ações que restabeleçam o equilíbrio econômico-financeiro de entidades em dificuldade ou, em casos de inviabilidade irreversível/ descontinuidade da operação, assegurar a devolução dos depósitos aos cooperados.

Além disso, afora a supervisão executada pelo conselho de administração, estão sujeitas à fiscalização do BACEN; submetidas à auditoria independente; sofrem auditoria interna direta e permanente de suas respectivas centrais, sem contar que muitas delas têm, adicionalmente, os seus próprios agentes de controles internos ligados ao conseIho de administração; são monitoradas indiretamente por suas centrais, confederações, seus bancos cooperativos (no que se refere à gestão de riscos de crédito, mercado e liquidez) e pelo fundo garantidor, e ainda dispõem de conselho fiscal.

Em síntese, além de movidas pelo compromisso com o bem-estar econômico e social dos sócios e das comunidades, as cooperativas são tão (ou mais) seguras quanto os melhores bancos brasileiros. Uma inequívoca evidência nesse sentido é o fato de apenas 9 (todas independentes/solteiras), de um universo médio de cerca de 1.150 
entidades, terem sido submetidas à decretação de regimes especiais pelo BACEN nos últimos cinco anos (2009-2014), ao passo que, no mesmo intervalo, 46 instituições financeiras convencionais, de um total de 776 (dez/14), passaram pela ação interventiva do órgão de supervisão. Ou seja, apesar de representarem $60 \%$ do conjunto das instituições financeiras do país, as cooperativas responderam por apenas $16 \%$ das intervenções feitas pelo BACEN no sistema financeiro nacional.

Estes são alguns dos muitos apelos para o incremento do quadro de beneficiários do cooperativismo financeiro brasileiro. Seguramente, há inúmeras outras razões que remetem para a causa da cooperação e a recomendam. Portanto, são também de todo justificáveis o apoio e o estímulo institucionais ao movimento cooperativo, representados, entre outras ações, pelo aprimoramento constante do marco regulatório e sua inclusão em Programas e Políticas de Estado e de Governo, neste caso especialmente quando os sócios estiverem entre os beneficiários das medidas.

Todo arcabouço de diferenciais justifica as diretrizes constitucionais para o Estado legislador, administrador ou juiz quanto a Liberdade, o Fomento e a Conformidade (Adequação) que devem pauta suas inter-relações com o Cooperativismo e as sociedades cooperativas.

Pelas mesmas razões, a presidente da República Federativa do Brasil, Dilma Rousseff, em entrevista à Revista Sicoob (edição de março de 2011), deixou explícita a importância do movimento para os rumos da nação, ao afirmar que "As cooperativas de crédito são atores essenciais no processo de desenvolvimento econômico do país, fundamentais para a democratização do crédito». Por isso, segundo ela, entre as principais propostas para o «Brasil seguir mudando» está a «continuidade do fortalecimento do cooperativismo de crédito»61.

O feixe de diferenciais estruturais e de propósitos projeta uma clara distinção entre as IFs Cooperativas e os bancos:

61 Entrevista concedida a Revista Sicoob, Ano 2, N. ${ }^{\circ}$ 5, jan/fev/mar 2011, p. 24/29. Disponível em http://www.sicoob.com.br/revistas 


\section{Bancos Cooperativas}

a) São sociedades de capital

b) O poder é exercido na proporção do número de ações

c) As deliberações são concentradas

d) Os administradores são terceiros (homens do mercado)

e) O usuário das operações é mero cliente

f) O usuário não exerce qualquer influência na definição dos produtos e na sua precificação

g) Podem tratar distintamente cada usuário

h) Preferem o público de maior renda e as maiores corporações

i) Priorizam os grandes centros (embora não tenham limitação geográfica)

j) Têm propósitos mercantilistas a) São sociedades de pessoas

b) O voto tem peso igual para todos (uma pessoa, um voto)

c) As decisões são partilhadas entre muitos

d) Os administradores-líderes são do meio (sócios)

e) O usuário é o próprio dono (cooperado)

f) Toda a política operacional é decidida pelos próprios usuários/donos (sócios)

g) Não podem distinguir: o que vale para um, vale para todos

(art. 37 da Lei n. ${ }^{\circ}$ 5.764/71)

h) Não discriminam, servindo a todos os públicos

i) Não restringem, tendo forte atuação nas comunidades mais remotas

j) A prática mercantil não é cogitada (art. 79, parágrafo único, da Lei n. ${ }^{\circ} 5.764 / 71$ )

k) A remuneração das operações e dos serviços não tem parâmetro/limite

k) O preço das operações e dos serviços tem como referência os custos e como parâmetro as necessidades de reinvestimento

I) Atendem em massa, priorizando, ademais, I) O relacionamento é personalizado/ indivio autosserviço dual, com o apoio da informática

m) Não têm vínculo com a comunidade e o m) Estão comprometidas com as comunidapúblico-alvo des e os usuários
n) Avançam pela competição
o) Visam ao lucro por excelência

n) Desenvolvem-se pela cooperação

o) O lucro está fora do seu objeto, seja pela sua natureza, seja por determinação legal (art. 3o da Lei n. ${ }^{\circ}$ 5.764/71)

p) O resultado é de poucos donos (nada é dividido com os clientes)

p) O excedente (sobras) é distribuído entre todos (usuários), na proporção das operações individuais, reduzindo ainda mais o preço final pago pelos cooperados e aumentando a remuneração de seus investimentos

q) No plano societário, são regulados pela Lei q) São reguladas pela Lei Cooperativista e das Sociedades Anônimas por legislação própria (Lei Complementar 130/09) 
Todas essas distinções podem ser melhor compreendidas ao se responder a seguinte pergunta: quais são, respectivamente, as origens e os objetivos de uma cooperativa e os de uma instituição financeira tradicional? A cooperativa nasce da vontade e da necessidade de um grupo de pessoas, que se congregam (elegem uma sociedade ou um fórum comum) para a troca (exercício da mutualidade) de soluções. Já a instituição financeira convencional surge da convicção e da iniciativa unilateral do dono do capital (ou do negócio) — sem qualquer consulta ao usuário- com o único objetivo de ampliar (rentabilizar) o capital investido.

Em outras palavras, na cooperativa prevalece o interesse do sócio (usuário), enquanto que numa instituição financeira comum impera (unicamente) o interesse do ofertador do serviço (dono do capital). Tanto na origem quanto no propósito, uma das partes do sistema financeiro se distingue inteiramente da outra, embora, por conveniência macrossistêmica, convivam sob uma unidade regulatória e supervisora.

A apreciação comparativa dos dois modelos organizacionais não deixa dúvida: cooperativa financeira não é banco e com banco não se confunde. Por isso mesmo, é vedado às primeiras o emprego do vocábulo «Banco» (Lei 5.764, de 1971, art. 5, parágrafo único).

\section{Práticas de gestão virtuosas: objetivos e desafios para um novo ciclo de crescimento sustentado}

Observando os melhores modelos ao redor do mundo e tomando como referência experiências exitosas no Brasil62, é possível eleger práticas desejáveis para um desenvolvimento mais representativo do cooperativismo financeiro brasileiro e que possa consolidar sua permanência no mercado financeiro em caráter permanente, projetando as melhores marcas de desenvolvimento econômico e social.

Dentro dessa perspectiva, traçando um paralelo entre o ideal e o real, propõe-se na sequência, a exposição sintética e dinâmica de um conjunto de grandes desafios —uma espécie de planejamento estratégico e respectivos planos táticos/de ação- que, alcançados, haverão de dar um novo impulso ao setor e conduzi-lo a um patamar mais próximo daquilo que representa o seu verdadeiro potencial:

62 Conteúdo extraído preponderantemente da obra de MEINEN, Ênio e PORT, Marcio. Cooperativismo financeiro: percurso histórico, perspectivas e desafios. Brasília: Editora Confebrás, 2014. 


\section{FIDELIZAÇÃO DOS SÓCIOS}

Objetivo: assegurar que os sócios, adotando a postura de donos do empreendimento, tenham na cooperativa, efetivamente, a sua principal ou, sempre que possível, única instituição financeira.

Desafio: são ainda muitas as situações em que o sócio mantém com a cooperativa apenas um subrelacionamento, servindo-se de uma ou outra operação ou serviço que, não raro, envolvem solução que a instituição financeira eleita como principal não faz questão de oferecer, ora por ser deficitária, ora por representar risco muito elevado. Por estar com um «pé» dentro do concorrente, o risco de deixar a cooperativa por inteiro é sempre iminente.

Fazendo uma comparação, hipotética, com outros empreendedores, a postura desses "sócios» que, como donos, desprestigiam a sua instituição financeira, corresponde à de um supermercadista que, em vez de consumir os seus produtos, vem a adquiri-los de outro supermercado, ou de um padeiro, que opta por comprar pão na padaria do vizinho. São, a toda evidência, comportamentos impensáveis, pois implicam abandono do próprio negócio.

Os mais ilustres entre os sócios infiéis, lamentavelmente, são os próprios dirigentes e conselheiros, além de funcionários das cooperativas - descaso que, na mesma proporção, alcança profissionais das entidades de segundo e terceiro níveis e empresas controladas-, incluindo os respectivos familiares, que têm o seu cartão de crédito emitido por outras instituições financeiras; o seguro e o consórcio feitos fora da cooperativa; os planos de previdência privada, em grandes fundos do mercado; os volumes altos de aplicações financeiras e os seus depósitos de poupança levados para instituições concorrentes, e assim por diante. Aliás, no rigor do estatuto social — quando se reporta aos deveres dos sócios e às consequências de seu não cumprimento-, essas situações configuram motivos de eliminação do quadro de cooperados, ou pelo menos de perda de condição básica para o exercício de cargo eletivo. Daí que é necessário:

a) começar por quem tem de dar o exemplo: nenhum conseIheiro, diretor ou funcionário da cooperativa ou de qualquer outra entidade do sistema associado deve manter relacionamento paralelo, exceto para valer-se de soluções ocasionalmente inexistentes na cooperativa ou banco cooperativo, cabendo-lhes ainda envidar todos os esforços para que os seus familiares sejam militantes ativos e cativos do cooperativismo financeiro; 
b) iniciar o lançamento de novos produtos e serviços sempre por esse mesmo público, com o que as soluções serão melhor assimiladas (para fins de comercialização) e a sua oferta, diante do exemplo dado pelos líderes, terá melhor aceitação no restante do quadro social;

c) conhecer o perfil dos sócios, um a um, para ver que produtos e serviços demandam. A partir disso, verificar o que é obtido junto a bancos, para redirecionar à cooperativa, e o que o cooperado ainda não consome, para oferecer, via cooperativa, a correspondente solução. É fundamental que os cooperados estejam na cooperativa de «corpo inteiro», sob pena de, a qualquer tempo, diante dos constantes assédios, migrarem por completo para a concorrência;

d) segmentar o quadro social por critérios de afinidade (pessoas físicas - produtores rurais; pessoas físicas - empreendedores urbanos; pessoas físicas - profissionais liberais; pessoas físicas assalariadas; pessoas jurídicas - microempresas e pequenas empresas; pessoas jurídicas - médias empresas...), visando a abordagens próprias e direcionadas para cada grupo, inclusive identificação de oportunidades para novos produtos e serviços;

e) criar novos produtos e serviços que possam despertar o interesse dos cooperados, evitando que a concorrência antecipe as suas ofertas;

f) premiar a fidelidade do sócio, especialmente pela precificação nos produtos e serviços (remuneração, taxas de juros, valor das tarifas etc.).

\section{AMPLIAÇÃO dA BASE DE COOPERAdOS, COM ÊNFASE NAS REGIÕES METROPOLITANAS}

Objetivo: aproveitar satisfatoriamente o potencial associativo, reduzindo a diferença entre sócios possíveis esócios efetivos.

Desafio: é ainda vastíssimo o universo de sócios a serem conquistados pelas cooperativas, sejam elas segmentadas, «semiabertas» ou de livre admissão, independente do território por elas ocupado. Nas regiões metropolitanas, a penetração é mínima (a representatividade no total dos empréstimos do setor fica aquém dos 30\%). Também entre a população jovem muito pouco se avançou, e o público feminino ainda não mereceu a atenção devida. No geral, inexiste até mesmo noção sobre o universo potencial de novos entrantes, o que faz com que o distanciamento não seja percebido. 
Há, ainda, inúmeros casos de cooperativas querendo ampliar as condições estatutárias de associação ou incorporar novas áreas geográficas, sem sequer terem atingido percentual minimamente razoável do contingente já disponível. Por outro lado, cooperativas com o dever de casa feito, altamente motivadas e preparadas para novos passos, são obrigadas a ficar assistindo à inatividade de coirmãs «sentadas» sobre generosas e inexploradas áreas de atuação, o que evidencia «reserva de mercado» improdutiva, iníqua e antissistêmica.

Para melhorar —e muito - o status nesse particular, as cooperativas (com o apoio de suas respectivas entidades sistêmicas), devem:

a) como primeira providência, promover um levantamento do mercado potencial de novos cooperados, com segmentação analítica dos diferentes públicos (perfis, localização geográfica etc.);

b) definir estratégias de abordagem para cada um dos grupos de potenciais entrantes, o que envolve ações de comunicação diferenciadas —incluindo os apelos próprios da solução cooperativa - e disponibilização de um amplo portfólio de produtos nos moldes do que é oferecido pelos grandes bancos de varejo;

c) dar atenção aos jovens — cuja abordagem deve contemplar as facilitações do mundo tecnológico e a ampla utilização das redes sociais - e às populações dos médios e grandes centros urbanos (pessoas físicas e jurídicas), âmbito no qual a aproximação passa pelo diálogo com lideranças de entidades associativas/de classe; pelo contato com formadores de opinião; pela aproximação com os veículos de comunicação; pelo ativismo em eventos de maior apelo popular; pelo envolvimento com movimentos de bairros, etc.;

d) ir em busca de uma presença mais acentuada do público feminino, cujas táticas de atração devem contemplar mecanismos de comunicação ajustados ao gosto do gênero e meios para o seu efetivo protagonismo na gestão da cooperativa (por exemplo: criação de núcleos específicos para elas e o estímulo para que componham os órgãos sociais);

e) delinear estratégias customizadas/específicas para atrair as micro, pequenas e médias empresas e os empreendedores individuais (envolvendo a força de trabalho e o portfólio), que são o «motor» do cooperativismo financeiro mais desenvolvido mundo afora; 
f) buscar uma maior aproximação com as cooperativas de outros segmentos, muitas delas com quadro social comum ao das cooperativas financeiras, dando efetividade ao princípio universal da intercooperação (horizontal);

g) ampliar a rede de atendimento sempre que a medida se fizer necessária para a redução da distância com grupos densos de potenciais sócios. No caso das regiões metropolitanas, em especial, deve-se fomentar, com os investimentos necessários, uma presença maciça de cooperativas mais universais (de livre admissão ou semiabertas), preferencialmente das com os melhores limites técnicos e profissionais mais preparados;

h) eliminar a reserva improdutiva de mercado, ou seja, permitir a realocação de áreas de atuação estatutária sempre que estas não sejam adequadamente exploradas, ao final de um prazo razoável. As cooperativas que compõem sistemas verticalizados, usando uma única marca, têm apenas a PREFERÊNCIA, e não a exclusividade, na exploração de áreas, em razão de proximidade geográfica, ou de (maior) afinidade com determinadas categorias de potenciais sócios. No momento em que essa «reserva» formal não se transformar em efetiva ocupação, é preciso dar lugar a quem queira e tenha competência para fazê-lo, cuja ação deve ser liderada, com firmeza e prontidão, pelas confederações e, especialmente, centrais. Enquanto isso não for feito, o espaço continuará sendo ocupado (em definitivo) pela concorrência, com prejuízo às comunidades e ao movimento cooperativo;

i) estabelecer metas (diárias, semanais, quinzenais, mensais, anuais e plurianuais) de conquista de (novos) sócios, por ponto de atendimento;

j) reciclar e recompor a sua força de trabalho, de modo que os profissionais da linha de frente, devidamente qualificados para entender e abordar os potenciais cooperados, conforme segmento de atuação, tenham uma ação mais arrojada e proativa na busca de novos sócios;

I) unir-se intersistemicamente nos investimentos e na formulação de ações de comunicação de massa, de modo a poderem divulgar os diferenciais do cooperativismo financeiro nos veículos e horários de mídia mais prestigiados pela população. 


\section{Postura sistêMICA}

Objetivo: valer-se adequadamente dos benefícios do ganho de escala, da economia de escopo e da sinergia entre as diferentes entidades do sistema associado.

Desafio: embora já se note apreciável evolução nesse particular, com exemplos louváveis dentro do movimento, para cumprir com os princípios sistêmicos da eficiência, da economicidade, da utilidade e da intercooperação, ainda se carece, no geral, de:

a) maior uniformização de políticas, produtos/serviços e processos;

b) sintonia mais fina entre os líderes das diferentes entidades federadas, porquanto ainda se percebe uma distância considerável em relação à almejada "coalização sistêmica» ou «coalização de comando»;

c) redução do paralelismo ou da sobreposição de estruturas e de ações em diversas áreas do relacionamento entre singulares, centrais, confederações e bancos cooperativos;

d) melhor aproveitamento das possibilidades de alocação corporativa de componentes organizacionais cujas atividades tenham repercussão sistêmica, especialmente nos campos do planejamento e da retaguarda operacional. Há que se identificar, de forma isenta (pensando apenas no sócio), o que deve realmente ser executado nas cooperativas, e do que, por conveniência, pode ser atribuído às demais entidades do sistema;

e) maior compromisso com soluções e projetos corporativos (negócios e retaguarda), de modo que, deliberados em ambientes sistêmico-participativos, sejam incondicionalmente cumpridos.

\section{UNIÃO ENTRE COOPERATIVAS}

Objetivo: aproveitar os benefícios do ganho de escala (limites operacionais, volumes $x$ política de precificação, expansão da rede e do número de sócios, etc.) e da racionalidade administrativa, ampliando as condições de competitividade.

Desafio: há ainda grandes oportunidades —e necessidade- de densificação desse movimento. São muitas as cooperativas que já não têm condições de atuar isoladamente, sendo que a junção com uma ou mais entidades coirmãs é o único caminho para evitar a descontinuidade, ou assegurar a permanência no mercado. 
Infelizmente, no geral, aspectos pessoais impedem uma maior efetividade desse processo. São questões relacionadas a cargos, nomes de cooperativas, locais das sedes, entre outros. Usualmente, não há um único argumento relacionado aos interesses dos sócios que sirva para desaconselhar as aglutinações. Entre as cooperativas centrais, âmbito em que igualmente se recomendam urgentes movimentos de unificação, as razões impeditivas são da mesma ordem.

Um avanço mais significativo nesse particular, indispensável diante dos cenários atual e futuro, passa pela adoção das seguintes medidas:

a) elaboração, pelas centrais, de detido diagnóstico sobre a situação presente e o potencial de cada uma das cooperativas singulares, identificando oportunidades e necessidades de unificação;

b) com base nesse retrato, planejamento de ações/movimentos de curto, médio e longo prazos;

c) priorização das incorporações envolvendo cooperativas que apresentem desiquilíbrio econômico-financeiro e não denotem capacidade de reação a curto prazo;

d) preferência por movimentos preventivos, com ênfase para a reunião de cooperativas cujos quadros sociais tenham afinidade imediata, sejam complementares entre si (ex.: cooperativas com sócios de perfil mais poupador unindo-se a cooperativas com cooperados mais demandadores de recursos) e/ou cujas áreas de atuação sejam coincidentes ou contínuas, induzindo o processo com vistas a um melhor aproveitamento das oportunidades de mercado;

e) por iniciativa das respectivas confederações, inserção das cooperativas centrais na pauta de discussões, pois as aglutinações nesse âmbito, além de convenientes e próprias para «servir de exemplo», já se constituem necessárias —e inadiáveis- em muitos casos.

\section{ESTRUTURA PATRIMONIAL}

Objetivo: manter, em todos os níveis da estrutura sistêmica, patrimônio adequado para os investimentos, as operações (limites) e o suporte aos riscos de crédito, mercado/liquidez, operacionais e outros (Basileia).

Desafio: a situação chega a ser de relativo conforto em um número razoável de cooperativas singulares, que adotam soluções criativas para 
angariar capital e ampliar reservas, ou que definem regras para capitalização contínua. Entretanto, na grande maioria das cooperativas, especialmente ao se considerar o volume de negócios que podem (ou devem) ainda alcançar, a estrutura de capital mostra-se acanhada. Também em grande parte das centrais, confederações e nos bancos cooperativos, tendo em vista a alavancagem mais aguda e o elevado nível de investimentos de sua responsabilidade, não há sobra de patrimônio. $\mathrm{O}$ quadro, no geral, indica que se deve:

a) adotar política corporativa (sistêmica) de gestão de capital, aproveitando a indução do ambiente normativo representado pela Resolução 3.988, de 30/6/2011, do Conselho Monetário Nacional (CMN) e também por conta de Basileia III, como medida preventiva, estruturada e permanente para fortalecer o patrimônio operacional em todos os níveis sistêmicos;

b) aproveitar melhor os recursos externos oferecidos para financiar a subscrição e integralização de novas quotas-partes de capital nas cooperativas singulares (ex.: Procapcred — programa de capitalização de cooperativas financeiras do Banco Nacional de Desenvolvimento Econômico e Social/BNDES- e recursos próprios geridos pelos bancos cooperativos);

c) buscar parcerias com entidades/organismos externos para atrair capital novo para os bancos cooperativos, a ser empregado no desenvolvimento de projetos de interesse comum;

d) insistir nas campanhas de capitalização, instituindo mecanismos criativos e recompensadores que estimulem a participação (o intercâmbio com entidades coirmãs é muito útil para ter contato com as melhores práticas);

e) ampliar as retenções de sobras para o fundo de reserva ou, ao menos, assegurar a conversão integral do excedente líquido em novas quotas-partes (a devolução de sobras em conta-corrente deve ser encarada como um privilégio para sócios de cooperativas altamente capitalizadas);

f) dar incentivos para que os sócios se sintam motivados a aportar novas quotas-partes, como: a remuneração anual na forma de pagamento de juros (a «calibragem» de sobras para o fundo de reserva não deve tirar a condição da adequada remuneração do capital); a possibilidade de resgate parcial futuro em dadas condições; a diferenciação nos critérios de precificação de produtos e serviços (tarifas etc.), bem como na apuração ou concessão de limites operacionais e na exigência de garantias para fornecimento de crédito. 


\section{Oferta de produtos e Serviços ecléticos e competitivos}

Objetivo: dispor de (e explorar) amplo portfólio de soluções negociais no interesse do sócio (com custo atraente, qualidade e comodidade de acesso), restringindo os apelos à infidelidade.

Desafio: embora já seja razoável a quantidade de produtos e serviços à disposição das cooperativas (especialmente quanto às soluções bancárias clássicas), há considerável espaço para aperfeiçoamentos, tanto na adequada exploração do portfólio, quanto no seu incremento.

Em cenário de diminuição dos ganhos com a atividade clássica da intermediação financeira, especialmente pela redução dos spreads, a exploração de atividades complementares baseadas em prestação de serviços é condição indispensável para recompor os níveis de receitas ou mesmo para a sobrevivência das cooperativas. $\mathrm{O}$ «combate à agiotagem», como objetivo central do (então) cooperativismo de crédito, deve dar lugar ao «atendimento integral» do sócio, com soluções sustentáveis (tanto para a cooperativa como para o sócio).

O cooperativismo financeiro investiu em demoradas articulações para ajustar o marco regulatório e vem alocando fartos recursos em TI e em alternativas de negócios para poder oferecer um portfólio pleno de produtos e serviços financeiros. O movimento está, decididamente, saindo de um modelo operacional simples e caminha rapidamente para um modelo operacional complexo. Não dá mais para voltar. O novo momento, definitivamente, conduz a uma aproximação com as instituições universais de varejo, que oferecem um portfólio multiproduto. Para tanto, há que se:

a) intensificar a oferta aos sócios e, conforme o caso, a terceiros, dos produtos e serviços já disponíveis (lembrando que os primeiros a experimentar/utilizar as soluções são os dirigentes, conselheiros e funcionários da cooperativa);

b) incrementar e aprimorar as soluções de modo a alcançar e manter equivalência com o portfólio dos grandes bancos de varejo, e assim dar um atendimento integral ao sócio (focar o relacionamento ao invés de um produto pontual, única forma de a cooperativa ser a única ou, ao menos, a principal instituição financeira do cooperado);

c) oferecer soluções integradas de gestão do fluxo de caixa (contas a receber e a pagar) às pessoas jurídicas, especialmente as micro, pequenas e médias empresas (que, como pessoas jurídicas, constituem o alvo das cooperativas); 
d) dar ênfase a produtos e serviços como cartões (incluindo os serviços de credenciamento/adquirência e domicílio bancário/cooperativo), seguros, cobrança, arrecadações (convênios de recoIhimento de tributos federais, estaduais e municipais; taxas e pagamentos diversos, tanto do setor público como do setor privado), consórcios, previdência privada, intermediação de quotas de fundos de investimento, captação de poupança rural, entre outros disponíveis no mercado;

e) aprimorar os processos de concessão e gestão do crédito, de modo a racionalizar os custos, tornar a liberação mais ágil e assegurar maior eficácia à sua cobrança;

f) aprimorar e fazer uso mais efetivo dos canais de atendimento não presenciais na oferta do conjunto de produtos e serviços;

g) dar condições - através dos investimentos para tanto exigidose promover diligências (cobrando e participando) para que as soluções corporativas/sistêmicas, normalmente concebidas no âmbito dos bancos cooperativos, confederações e/ou centrais, sejam mais efetivas, tanto na rapidez da entrega, quanto na adequabilidade e na competitividade (qualidade, custo e comodidade).

\section{GOVERNANÇA}

Objetivo: dispor de uma gestão legitimada, participativa e profissional, combinando soluções que considerem a defesa dos interesses dos sócios e respeitem os padrões técnicos de mercado.

Desafio: aqui também é correto afirmar que, mais recentemente, especialmente por movimentos de indução do Banco Central do Brasil e como resultado da evolução conceitual e técnica dos dirigentes, boa parte das cooperativas vêm apresentando bons exemplos de governabilidade. Contudo, mesmo nessas entidades mais avançadas, e muito mais nas outras, há oportunidades para aprimoramentos, destacandose:

a) a necessidade de revisitação da política e das práticas de representatividade do quadro social (todas as comunidades e grupos homogêneos/afins devem sentir-se parte da cooperativa);

b) a criação de meios/canais apropriados para atrair o interesse e a participação dos sócios (processos de nucleação; reuniões locais, pré-assembleias etc.); 
c) o empenho para o aperfeiçoamento estratégico e técnico dos conselheiros e diretores (participação em eventos de capacitação, especialmente os promovidos pelas entidades de segundo e terceiro níveis do sistema sócio), e também para uma dedicação mais substantiva (tempo de expediente) aos interesses da cooperativa/do quadro social;

d) a busca por uma maior fidelidade aos modelos de governança definidos sistemicamente e apoiados pelo Banco Central;

e) a preparação de vigoroso plano de sucessão, desde as cooperativas singulares até as entidades de terceiro nível (bancos cooperativos e confederações), especialmente no âmbito das lideranças encarregadas da direção estratégica e da gestão executiva.

\section{GESTÃO DE PESSOAS}

Objetivo: instituir políticas de gestão de pessoas que permitam atrair e reter os bons profissionais, e mantê-los em sintonia com os objetivos da organização.

Desafio: talvez aqui residam as maiores deficiências, considerando o conjunto do cooperativismo financeiro (reconhecidas, com louvor, as exceções pontuais). As razões, possivelmente, concentram-se na forma como alguns dirigentes ainda veem as cooperativas, não as reconhecendo como verdadeiras empresas, que atuam em um mercado complexo e altamente competitivo.

O fato é que não se consegue fazer a diferença com pessoas pouco qualificadas e/ou desmotivadas. Logo, se não houver um ambiente acolhedor para os bons profissionais nas cooperativas, com remuneração, benefícios, política de investimentos em formação/capacitação e perspectivas de crescimento de acordo com o mérito, estes farão sempre a opção por empresas que valorizem tais fundamentos, muitas vezes concorrentes diretas.

No campo específico da escolha do perfil profissional e da preparação da força de trabalho, há que se admitir que, no geral, o "faro» e a «pegada» para os negócios estão muito aquém do desejável. Nesse novo momento, considerando o tamanho do mercado a conquistar, é preciso contar com profissionais mais arrojados e doutrinados na seara comercial, destes que se sentem à vontade para ir ao encontro dos sócios e dos potenciais cooperados. Já foi o tempo de «esquentar a cadeira» por detrás do balcão de atendimento, esperando o «cliente» chegar. Hoje, aliás, todos os colaboradores da co- 
operativa, independente do seu papel central (incluindo o presidente e os caixas...), devem permanentemente pensar em negócios e, de alguma forma, contribuir para que estes se concretizem, mantida, obviamente, a preocupação com a segurança e a sustentabilidade das operações.

Nesse campo, as práticas virtuosas (e vitoriosas) passam essencialmente:

a) pela contratação (e retenção) apenas de pessoas de «bem com a vida»;

b) pela eliminação de profissionais descomprometidos e sem motivação/entusiasmo para dar o seu melhor, incluindo dirigentes;

c) pela aplicação das soluções sistêmicas de gestão de pessoas, concebidas por profissionais preparados e conhecedores das especificidades do segmento cooperativo financeiro;

d) pela instituição de plano de cargos, salários e benefícios que assegure o nivelamento das remunerações com o mercado (incluindo premiação por produtividade), respeitando a proporcionalidade (tamanho) e a condição econômico-financeira de cada entidade;

e) pelo reconhecimento, nas movimentações, do mérito individual;

f) pela concessão de incentivos de longo prazo (ex.: previdência privada patrocinada), que estimulem a permanência/a fidelidade;

g) pela definição de prioridades de capacitação (do > para o < impacto em negócios e riscos), após diagnóstico sobre o estágio presente (planejamento do processo de capacitação);

h) pela aplicação dos conteúdos e das metodologias de capacitação sistêmicos;

i) pelo envolvimento efetivo/intensivo das equipes alocadas nas entidades de segundo e terceiro níveis do sistema associado e empresas corporativas, na preparação da força de vendas (campo dos negócios);

j) pela associação da capacitação (visando ao domínio sobre os produtos e serviços —incluindo a sua repercussão no resultado-, bem como sobre as técnicas de vendas a serem empregadas em sua oferta aos sócios e terceiros) a um plano vigoroso de metas por produto e serviço disponíveis na cooperativa, subdividido por ponto de atendimento. 


\section{EducaçÃo CoOperativista}

Objetivo: eliminar os riscos decorrentes da ausência de conhecimentos adequados e que colocam em risco o equilibrio e a expansão coerente ${ }^{63}$ das cooperativas.

Desafio: não é sem razão que a temática da educação moral cooperativista é apontada com o maior de todos os vetores de sucesso das cooperativas em geral e das cooperativas de crédito em específico $^{64}$. Tudo nas cooperativas impõe um comportamento adaptado, cuja compreensão é indelevelmente retardada pela ausência de políticas públicas de fomento pela educação, pelas graves lacunas acadêmicas nas universidades e pela ostensiva preponderância da competitividade, do individualismo e demais métodos característicos do modelo de produção e de consumo hegemônicos. A cooperativa "Sobre todo, deberá formar hombres», posto que, ao contrário do capitalismo, «El cooperativismo es mucho más sensible a la cualidad humana» ${ }^{65}$.

Apenas a título de mínima ilustração, vale a remissão ao papel crucial desempenhado, nessa temática, no seio da cooperativa dos Probos Pioneiros de Rochdale que, com arraigado esforço, superou sucessivas manifestações de desafios análogos aos contemporâneos das «cooperativas de crédito», tanto internos à sociedade, quanto os de mercado, mas identificado na educação do quadro social a raiz primária do sucesso:

«É necessário advertir que a previdente deliberação de destinar $2 \frac{1}{2} \%$ dos lucros líquidos à educação geral, foi que elevou tanto na consideração pública a Sociedade Cooperativa de Rochdale. Foi esta 'regra de ouro' que the deu tanto valor, que Ihe conquistou a simpatia de tantos amigos e lhe angariou fama universal. Foi esta regra que, tendo contribuído para o progresso intelectual e moral dos cooperadores, preservou a Sociedade do perigo de ver os seus estatutos retocados por pessoas ignorantes ou mal informadas, que não faltariam ali, certamente como em qualquer outra parte, que anulou os esforços para destruir as ideias mais sãs e características da

63 Ao tratar da coerência da expansão das cooperativas, estamos fazendo o claro registro da necessidade de não dissociar crescimento e manutenção das características essenciais das cooperativas (identidade), temática tão antiga e que ainda faz tropeçar em crises cíclicas o Cooperativismo. Veja, à guisa de exemplo, o que consigna LASSERRE, Georges. El Cooperativismo. Barcelona: Oikos-tau, 1972, p. 117/118.

64 PINHO, Diva Benevides. Brasil: crédito cooperativo e sistema financeiro. São Paulo: Esetec, 2006, p. 18.

65 Idem, p. 119.

Boletín de la Asociación Internacional de Derecho Cooperativo 
Sociedade de Rochdale, porque os ignorantes estão sempre dispostos a admitir que a inteligência não produz dinheiro, ao passo que sem inteligência não haveria economias e lucros nos armazéns cooperativos nem em outro lugar nenhum» ${ }^{66}$.

Em essência, o que se espera de uma cooperativa protagonista no sistema financeiro é que ela seja a principal, quando não única, instituição financeira dos seus sócios. Para isso requer-se:

1) que disponha —e faça uso proativo- de um completo portfólio de produtos e serviços;

2) que reúna uma governança virtuosa e uma equipe tecnicamente qualificada;

3) que demostre eficiência operacional, dando ênfase a ações que levem ao ganho de escala e promovam economia de escopo;

4) que ostente tecnologia de ponta, como medida de economia, pela automação de processos, e mecanismo indutor de negócios;

5) que amplie e aprimore os canais de atendimento (presenciais e remotos);

6) que esteja mais presente nos médios e grandes centros urbanos;

7) que se apresente efetivamente como uma entidade regional forte e comprometida com os anseios da comunidade/grupo/ categoria/classe nela representados.

As iniciativas aqui recomendadas, se aplicadas em sua essência, certamente farão diminuir a amplitude das dificuldades atuais, contribuindo, assim, para que se encurte o caminho que separa o setor dos almejados dois dígitos (ou do "dígito superior») de participação no mercado, assegurando a sua consolidação.

Conquanto os inúmeros desafios arrolados, o cooperativismo financeiro conta, hoje, com generosas prerrogativas legais e regulamentares, que são amplamente permissivas em termos operacionais, e goza de amplo prestígio institucional (governo, sociedade, mídia, etc.). Com isso, todas as soluções circunscrevem-se aos seus próprios domínios.

66 HOLYOAKE, G.J. Os 28 tecelões de Rochdale. (História dos probos pioneiros de Rochdale). Rio de Janeiro: Livraria Francisco Alves, 1933, p. 123. Disponível em http:// www.dominiopublico.gov.br. 
A boa iniciativa e disposição para fazer crescer o cooperativismo financeiro de forma adequada, compatível, sem perda de identidade, mas pujante, é único vetor que se impõe atualmente no Brasil, afora as questões macroeconômicas.

\section{IV. À Guisa de Conclusão}

O modelo diferencial estrutural das IFs cooperativas justifica a defesa do sistema cooperativo financeiro, razão de todos os resultados benéficos para um efetivo desenvolvimento socioeconômico sustentado.

De toda a exposição, mais sumária do que cabível para a análise profundidade de que o tema é credor, ainda assim é concluir pelo reconhecimento de que, conquanto o ambiente regulatório seja muito mais favorável e estável para as instituições financeiras cooperativas, o apoio e a criação de condições jurídicas favoráveis deve se atrelar muito mais ao dirigismo constitucional acerca da ordem econômica que a mera discricionariedade da Administração Pública. A abertura de mercado para as IFs cooperativas vincula-se essencialmente à política de Estado e não à política de governo.

A mesma abertura atual do mercado financeiro às cooperativas exige o aproveitamento da oportunidade pelo sistema financeiro cooperativo de maior protagonismo no desenvolvimento socioeconômico sustentado, para o qual suas estruturas jurídico-operacionais, seus valores fundamentais e éticos e seus princípios estão indelevelmente vocacionados.

A boa governança, adequada às particularidades do modelo econômico das cooperativas, deve ser chave para a confirmação do diferencial que justifica a defesa do sistema.

Para o propósito de comprovar e perenizar na sociedade civil e poder público a superioridade desse sistema socioeconômico, práticas estratégicas e adequadas de gestão — tais como fidelização dos cooperadores, ampliação estratégica da base de sócios, intercooperação sistêmica, adequação patrimonial-operacional, variação e competitividade de produtos e serviços, investimento em gestão e em bons profissionais; educação cooperativista, entre outras - devem permear o funcionamento e crescimento estratégico dessas sociedades, finalmente com preservação de sua identidade.

É fundamental o aproveitamento da conjuntura para produzir empresas arrojadas efetivamente cooperativas e consolidar no modelo de desenvolvimento nacional o sistema financeiro cooperativo. 


\section{Bibliografia}

BECHO, Renato Lopes. Elementos de Direito Cooperativo (de acordo com o Código Civil). São Paulo: Dialética, 2002.

BENECKE. Cooperação e desenvolvimento. O papel das cooperativas no processo de desenvolvimento econômico nos países de Terceiro Mundo. Porto Alegre: Coorjornal, 1980.

BULGARELLI, Waldirio. As sociedades cooperativas e sua disciplina jurídica. 2. ${ }^{\text {a }}$ ed., Rio de Janeiro: Renovar, 2000.

CANOTILHO, J.J. Gomes. Direito constitucional e teoria da constituição. 7. ${ }^{a}$ ed. Coimbra: Almedina, 2003.

CANOTILHO, J.J. Gomes, MENDES, Gilmar Ferreira, SARLET, Ingo Wolfgang e STRECK (Coords.). Comentários à Constituição Federal do Brasil. São Paulo: Saraiva/Almedina, 2013.

CARVALHOSA. Modesto. Direito econômico: obras completas. São Paulo: Revista dos Tribunais, 2013.

CRACOGNA, Dante. O Acto Cooperativo. Artigo em NAMORADO, Rui e OLIVEIRA, Celso Claro de (coord). Pensamento Cooperativo - As Relações entre Cooperativas e Cooperadores, n. ${ }^{\circ}$ 3- ano 3. Lisboa: Tipografia Peres, 2002.

DE ROSE, Marco Túlio. A Interferência Estatal nas Cooperativas (Aspectos Constitucionais, Tributários, Administrativos e Societários). Porto Alegre: Sergio Antonio Fabris Editor, 1988.

FREITAS, Juarez. Sustentabilidade: direito do futuro. Belo Horizonte: Fórum, 2011. FRANK, Walmor. Direito das Sociedades Cooperativas. São Paulo: Saraiva, 1973. GAUDIO, Ronaldo Chaves; FARIAS, Eduardo Helfer de. Barreiras da razão indolente ao Cooperativismo: violação e incompreensão das características essenciais das sociedades cooperativas como fatores de prejuizo socioeconômico. Artigo in Anais do $4^{\circ}$ Seminário Interdisciplinar em Sociologia e Direito. Niterói: Ed. PPGSD-UFF, 2014.

GARCIA, Flavio Amaral e GAUDIO, Ronaldo. Administração Pública e Cooperativismo; em MENDES, Gilmar Ferreira e BRANCO, Paulo Gustavo Gonet (org). III Seminário Internacional de Direito Administrativo e Administração Pública: gestão pública - inovações, eficiência e cooperação no âmbito da administração pública. Brasília: IDP, 2014.

GREMAUD, Amaury Patrick e BRAGA, Mauro Bobik. Teoria dos Jogos: Uma Introdução. In: PINHO, Diva Benevides e VASCONCELLOS, Marco Antônio Sandoval de (org.). Manual de Economia. 3. ${ }^{a}$ ed., São Paulo: Saraiva, 1998.

GRAU, Eros Roberto. A ordem econômica na constituição de 1988. 17. a ed., São Paulo: Malheiros, 2015.

HARNECKER, Camila Piñedo (coord). Cooperativas e socialismo: uma mirada desde Cuba. La Habana: Editorial Caminos, 2012.

HOLYOAKE, G.J. Os 28 tecelóes de Rochdale. (História dos probos pioneiros de Rochdale). Rio de Janeiro: Livraria Francisco Alves, 1933.

LASSERRE, Georges. El Cooperativismo. Barcelona: Oikos-tau, 1972.

LUZ FILHO, Fábio. O direito cooperativo. Rio de Janeiro: Irmaõs Pongetti Editora, 1962. 
MACKAAY, Ejan; Rosseau, Stéphane. Análise econômica do Direito. 2. ${ }^{a}$ ed., São Paulo: Atlas, 2015.

MEINEN, Ênio e PORT, Marcio. Cooperativismo financeiro: percurso histórico, perspectivas e desafios. Brasília: Editora Confebras, 2014.

MELO SOBRINHO, Abelardo Duarte de; TOMBINI, Alexandre. Artigo em PINHO, Diva Benevides e coord.). O Cooperativismo de Crédito no Brasil do século XX ao século XXI. Brasília: Ed. Confebras, 2010.

MIRANDA, José Eduardo. De La Crisis de Identidad Al Rescate de La Génesis Del Cooperativismo. Madrid: Dykinson S.L., 2012.

MOURA, Waldiki. Curso Médio de Cooperativismo. Rio de Janeiro: Ministério da Agricultura, 1968.

MUSA, Orestes Rodríguez. Socialismo, Cooperativismo y Derecho. Dialética necessária para la actualización del modelo económico cubano, artigo em Boletín de la Asociación Internacional de Derecho Cooperativo, n. ${ }^{\circ} 46$. Bilbao/ES: Publicaciones de la Universidad de Deusto, 2012.

NAMORADO, Rui. Introdução ao Direito Cooperativo - para uma expressão jurídica da cooperatividade. Coimbra: Almedina, 2000.

PINHO, Diva Benevides. Sistema Econômicos Comparados. São Paulo: Saraiva: Editora da Universidade de São Paulo, 1984.

PINHO, Diva Benevides. Brasil: crédito cooperativo e sistema financeiro. São Paulo: Esetec, 2006.

PUENTE, Antônio Salinas. Derecho Cooperativo. México: Editorial Cooperativo, 1954.

SERGIO, Antônio. Cooperativismo de Crédito; capítulo em SERGIO, Antônio (coord.), O Cooperativismo - objectivos e modalidades. Porto: CENTROCOOPE.

SOUTO, Marcos Juruena Villela. Direito Administrativo da Economia. 3. ${ }^{\circ}$ Ed, Rio de Janeiro: Lumen Juris, 2003.

SOUZA, João Batista Loredo de; MEINEN, Ênio. Cooperativas de Crédito: Gestão Eficaz. Brasília: Editora Confebras, 2010.

TOMBINI, Alexandre. Desafios para o crescimento do cooperativismo de crédito na visão do Banco Central. Artigo em Conjuntura e Perspectivas do Cooperativismo de Crédito. Publicação coordenada pela Gerência de Apoio ao Desenvolvimento em Mercados (Gemerc). Brasilia: SESCOOP, 2008.

WARBASSE, James Peter. Democracia Cooperativa. Buenos Aires: Arengreen, 1975.

\section{Outras fontes}

PINHEIRO, Armando Castelar; e SADDI, Jairo. Curso de law and economics. Disponível em http://www.iadb.org/res/laresnetwork/files/pr251finaldraft.pdf.,

REVISTA SICOOB, Ano 2, N. 5, jan/fev/mar 2011, p. 24/29. Disponível em http://www.sicoob.com.br/revistas

REVISTA SICOOB, Ano 2, N. ${ }^{\circ}$ 6, abr/mai/jun 2011, p. 22/26. Disponível em http://www.sicoob.com.br/revistas 